\title{
Gas-Phase Nazarov Cyclization of Protonated 2-Methoxy and 2-Hydroxychalcone: An Example of Intramolecular Proton-Transport Catalysis
}

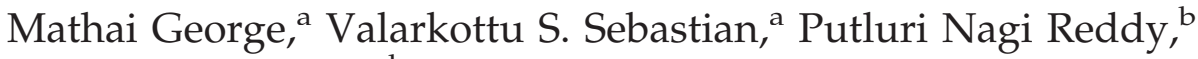 \\ Ragampeta Srinivas, ${ }^{b}$ Daryl Giblin,, ${ }^{\text {c, }}$ and Michael L. Gross ${ }^{\mathrm{c}}$ \\ ${ }^{a}$ Department of Chemistry, Sacred Heart College, Thevara, Cochin, Kerala, India \\ ${ }^{\mathrm{b}}$ National center for Mass Spectrometry, IICT, Hyderabad, India \\ ${ }^{\mathrm{c}}$ Department of Chemistry, Washington University in St. Louis, St. Louis, Missouri, USA
}

\begin{abstract}
Upon CA, ESI generated $[\mathrm{M}+\mathrm{H}]^{+}$ions of chalcone (benzalacetophenone) and 3-phenylindanone both undergo losses of $\mathrm{H}_{2} \mathrm{O}, \mathrm{CO}$, and the elements of benzene. CA of the $[\mathrm{M}+\mathrm{H}]^{+}$ ions of 2-methoxy and 2-hydroxychalcone, however, prompts instead a dominant loss of ketene. In addition, $\mathrm{CA}$ of the $[\mathrm{M}+\mathrm{H}]^{+}$ions of 2-methoxy- $\beta$-methylchalcone produces an analogous loss of methylketene instead. Furthermore, the $[\mathrm{M}+\mathrm{D}]^{+}$ion of 2-methoxychalcone upon CA eliminates only unlabeled ketene, and the resultant product, the $\left[\mathrm{M}+\mathrm{D}-\right.$ ketene $^{+}$ion, yields only the benzyl- $d_{1}$ cation upon CA. We propose that the 2-methoxy and 2-hydroxy (ortho) substituents facilitate a Nazarov cyclization to the corresponding protonated 3-arylindanones by mediating a critical proton transfer. The resultant protonated indanones then undergo a second proton transport catalysis facilitated by the same ortho substituents producing intermediates that eliminate ketene to yield 2-methoxy- or 2-hydroxyphenylphenyl-methylcarbocations, respectively. The basicity of the ortho substituent is important; for example, replacement of the ortho function with a chloro substituent does not provide an efficient catalyst for the proton transports. The Nazarov cyclization must compete with an alternate cyclization, driven by the protonated carbonyl group of the chalcone that results in losses of $\mathrm{H}_{2} \mathrm{O}$ and $\mathrm{CO}$. The assisted proton transfer mediated by the ortho substituent shifts the competition in favor of the Nazarov cyclization. The proposed mechanisms for cyclization and fragmentation are supported by high-mass resolving power data, tandem mass spectra, deuterium labeling, and molecular orbital calculations. (J Am Soc Mass Spectrom 2009, 20, 805-818) (c) 2009 American Society for Mass Spectrometry
\end{abstract}

$\mathrm{T}$ The acid-catalyzed cyclization of divinyl ketones to yield cyclopentenones is known as Nazarov cyclization, a reaction that was recently reviewed $[1,2]$. Bronsted acids, superacids, and Lewis acids are usually needed to promote the cyclizations in solution. The mechanism involves conrotatory electrocyclic ring closure of a protonated divinyl ketone followed by deprotonation and double-bond reorganization [2]. A general and efficient method for the synthesis of biologically active 3-aryl-indanones is the Nazarov cyclization of substituted chalcones [3-6]. A variety of indanone derivatives can be synthesized by the microwave-assisted Nazarov cyclization of chalcones in trifluoroacetic acid (TFA) solution [5]. In addition, further motivation comes from the antimicrobial activity of substituted chalcones, which was evaluated recently [7].

Address reprint requests to Dr. M. George, Department of Chemistry, Sacred Heart College, Thevera, Cochin, Kerala 682013, India. E-mail: georgem_ mathai@yahoo.co.in and Dr. D. Giblin, Department of Chemistry, Washington University, 1 Brookings Drive, Campus Box 1134, St. Louis, MO 63130, U.S.A. E-mail: giblin@wustl.edu

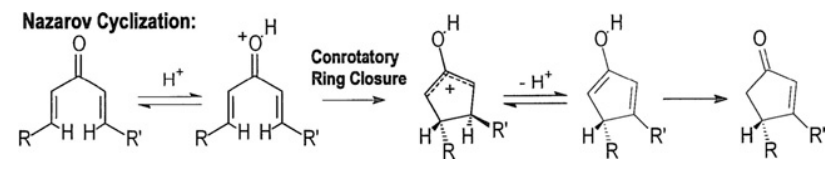

Characterization of these materials has attracted the attention of mass spectrometrists since the early 1960s [8]. The formation and structures of the $[\mathrm{M}-\mathrm{H}]^{+}$ion and $[\mathrm{M}-\mathrm{H}-\mathrm{CO}]^{+}$ions from the $\mathrm{M}^{+}$, were one focus [9-14], including an ion-structure study with an iontrap mass spectrometer [15]. Recently, the mechanisms for elimination of $\mathrm{C}_{6} \mathrm{H}_{6}$ and $\mathrm{CO}$ from the atmospheric pressure chemical ionization (APCI)-generated $[\mathrm{M}+\mathrm{H}]^{+}$ions of chalcones were established [16]. Three important product ions observed in the CAD mass spectrum of protonated chalcone arise from losses of $\mathrm{H}_{2} \mathrm{O}, \mathrm{CO}$, and $\mathrm{C}_{6} \mathrm{H}_{6}$. Studies of the substituted chalcones show that both of the phenyl rings are eliminated as the neutral arenes.

We took a different tack and describe here the possibility of conducting the Nazarov cyclization of chalcones in the gas phase by using a mass spectrome- 
ter as both reactor and detector. Investigations of gasphase reactions conducted using advanced experimental techniques in mass spectrometry and supported by theoretical calculations provide a means for understanding energetics and intrinsic mechanisms of reactions at the molecular level [17, 18]. Ionization methods such as CI and ESI are effective for protonating organic molecules while MS/MS and molecular modeling are widely used for the elucidation of gas-phase structures and fragmentation mechanisms. Proton-induced, gasphase rearrangements may closely parallel those in solution as demonstrated by mass spectrometric studies; the acid-catalyzed Claisen rearrangement being a classic example [19]. A more recent example is the rearrangement of protonated 2-[N-benzoyloxyphenyl] benzamide both in the gas phase and in solution [20]. Another motivation for our study relies on evidence from both experiment and theory that high-energy $1,3-\mathrm{H}$ shifts take place in the gas phase when catalyzed by a base, a process called proton transport catalysis [21-24]. The catalysis of the gaseous acetone radical cation enolization by benzonitrile $[25,26]$ and methanol [27] as well as the isomerizations of isoformyl/formyl cations by various neutrals [22] of ionized acetaldehyde by methanol are such examples [28].

We expected that ESI or CI methods protonate chalcones at the carbonyl oxygen, affording species that could potentially undergo Nazarov type cyclizations in the gas phase. An important step in the solution Nazarov cyclization is deprotonation. A substituent such as $\mathrm{OCH}_{3}$ or $\mathrm{OH}$ at the ortho position may be sufficiently basic to cause deprotonation or otherwise assist in proton transport. Given that the $\mathrm{OCH}_{3}$ and $\mathrm{OH}$ groups are capable of catalyzing proton migrations in the gas phase [27, 28], we chose to synthesize the following chalcones (substituted benzalacetophenones): chalcone (1), isomeric methoxy chalcones (2 and 5), isomeric hydroxy chalcones (4 and 6), 2-methoxy- $\beta$-methyl-chalcone (2-methoxybenzal-propiophenone) (3), and 2-chlorochalcone (7) for this investigation. In addition, benzhydrols $\mathbf{8}, \mathbf{9}$, and 10 were synthesized and used to generate reference ions.

\section{Experimental}

\section{Materials}

Chalcones 1 to 7 were synthesized by standard procedures $[9,29,30]$ with focus on various substituents at the 2- and 4-position of the ' $a$ ' ring. The benzhydrols used for generating product ions for comparison were synthesized by procedures already reported [31]. Purity of the samples was checked by TLC, and the structures confirmed by NMR, IR and mass spectra (Supplemental Materials, which can be found in the electronic version of this article). 3-Phenylindanone was purchased form Aldrich Chemical Co. (Milwaukee, WI).

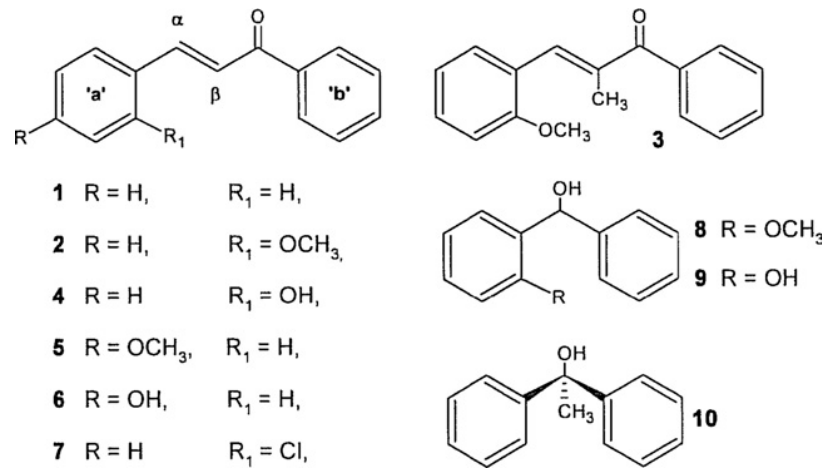

\section{Mass Spectrometry}

Instrumental methods. Formation of $[\mathrm{M}+\mathrm{H}]^{+}$ions was achieved by protonation of the chalcones by CI (chemical ionization) and ESI (electrospray ionization) methods. The $[\mathrm{M}+\mathrm{H}]^{+}$ions were analyzed by MS and tandem MS/MS and $\mathrm{MS}^{3}$ methods by using MI (metastable ion) or CA (collisional activation) under either low-energy ( $<100 \mathrm{eV}$, laboratory) or high-energy (4 $\mathrm{keV}$, laboratory) conditions.

The CI experiments, both MS and high-energy CA MS/MS, were conducted on a VG ZAB-T four-sector mass spectrometer (Manchester, UK) of BEBE design [32]. MS1 was a standard high-resolving power, doublefocusing mass spectrometer (ZAB) of reverse geometry. MS2 possessed a prototype Mattauch-Herzog-type design, incorporating a standard magnet and a planar electrostatic analyzer having an inhomogeneous electric field, a single-point, and an array detector. Samples were introduced by evaporation from a direct-insertion probe; and ions formed were accelerated to $8 \mathrm{keV}$. The dissociation of the precursor ion (MI or CAD) was studied in the third field-free region. For CA, sufficient helium gas was added to the collision cell, which was floated at $4 \mathrm{kV}$, to decrease the main beam intensity by $30 \%$ for CAD experiments. Both MS1 and MS2 were operated at a mass resolving power of 1000 . Typically 10 to 20 scans were signal averaged for each spectrum. Data acquisition and workup were accomplished by using a VAX 3100 workstation working with OPUS software (VG, Manchester, UK).

The ESI-generated ions were produced from samples dissolved in 1:1 mixture of acetonitrile and water (10-20 $\mu \mathrm{g} / \mathrm{mL}$ ) and introduced by direct infusion at a flow rate of $10 \mu \mathrm{L} / \mathrm{min}$ for both MS and low-energy tandem MS analyses.

Some ESI and MS/MS experiments were conducted by using a Micromass Q-TOF-Ultima GLOBAL mass spectrometer (Manchester, UK) operated in the positive-ion mode. The needle voltage was $3 \mathrm{kV}$, and the cone voltage was $90 \mathrm{~V}$. The temperatures of the source block and desolvation region were 90 and $150{ }^{\circ} \mathrm{C}$, respectively. All parameters (i.e., aperture to the TOF, transport voltage, offset voltages) were optimized to achieve maximum sensitivity and a mass resolving 
Table 1. CAD mass spectra of ESI-produced $[\mathrm{M}+\mathrm{H}]^{+}$ions (quadrupole ion trap)

\begin{tabular}{|c|c|c|c|c|c|c|c|}
\hline \multirow[b]{2}{*}{ Compound } & \multicolumn{7}{|c|}{ Fragment ions: $m / z$ (abundance) } \\
\hline & $-\mathrm{H}_{2} \mathrm{O}$ & $-\mathrm{CO}$ & $-\mathrm{C}_{6} \mathrm{H}_{6}$ & $-\mathrm{C}_{6} \mathrm{H}_{5} \mathrm{R}$ & $\begin{array}{c}- \text { Ketene } \\
(- \text { Methyl Ketene* })\end{array}$ & Benzoyl m/z 105 & $m / z 103$ \\
\hline Chalcone (1) & $191(13)$ & $181(14)$ & $131(100)$ & & ND & (10) & (4) \\
\hline 3-Pphenylindanone & $191(2)$ & $181(1)$ & $131(100)$ & & ND & ND & (6) \\
\hline 2-Methoxychacone (2) & ND & ND & ND & ND & $197(100)$ & (2) & ND \\
\hline 2-Methoxy- $\beta$-methylchalcone (3) & $235(32)$ & ND & ND & ND & *197 (100) & ND & ND \\
\hline 2-Hydroxychalcone (4) & ND & ND & ND & ND & $183(100)$ & $(80)$ & ND \\
\hline 4-Methoxychalcone (5) & $221(28)$ & $211(24)$ & $161(100)$ & $131(33)$ & ND & (55) & (3) \\
\hline 4-Hydroxychalcone (6) & $207(28)$ & $197(25)$ & $147(100)$ & $131(22)$ & ND & (41) & (2) \\
\hline 2-Chlorochalcone (7) & $225(14)$ & $215(9)$ & $165(100)$ & $131(26)$ & $201(2)$ & (4) & (8) \\
\hline
\end{tabular}

power of 15,000 (full width at half maximum). The CAD experiments were carried out by mass selecting the precursor ion by using the quadruple analyzer, and the product ions were obtained by using the time-of-flight analyzer operated at a mass resolving power of 15,000 (' $w$ ' mode). Collision voltages for fragmenting the ions were in the range of 7 to $10 \mathrm{~V}$ with Ar as collision gas. Accurate masses of the product ions were determined by using the precursor ion as the internal standard.

Some ESI MS and low-energy MS/MS and tandem $\mathrm{MS}^{3}$ experiments were performed by using a Thermo Finnigan LCQ Advantage or a Thermo Finnigan LCQ Classic 3D ion-trap mass spectrometers (San Jose, CA).

Isotopic labeling. To track fragmentation pathways, $[\mathrm{M}+$ $\mathrm{D}]^{+}$ions were generated by using $\mathrm{CD}_{4} \mathrm{CI}$ and were analyzed by high-energy $\mathrm{CA}$ and MI methods. In addition, $[\mathrm{M}+\mathrm{D}]^{+}$ions were generated by ESI from 1:1 $\mathrm{D}_{2} \mathrm{O}$ /acetonitrile mixture, introduced by direct infusion $(10 \mu \mathrm{L} / \mathrm{min})$ and analyzed by CA MS/MS and $\mathrm{MS}^{3}$ on the LCQ Classic ion trap.

\section{Theoretical Calculations}

Owing to the large size of chalcones, many of the initial scans of the potential energy surfaces were performed by using the PM3 $[33,34]$ semi-empirical algorithm, where PM3 was part of the Spartan '02 for Linux package (Wave Function, Inc. Irvine, CA). Further characterization was by density functional theory (DFT), which requires less computational overhead than do formal ab initio methods and yet incorporates dynamic correlation, has little spin contamination [35-37], and usually performs adequately giving proper geometries, energies, and frequencies [38]. DFT was part of the Gaussian 98/03 suite (Gaussian, Inc. Wallingford, CT) $[39,40]$. Minima and transition states were optimized at the level B3LYP/6-31G(d, p) and confirmed by vibration frequency analysis. Connections of transition states to minima were analyzed by combination of inspection, projection along normal reaction coordinates, or reactionpaths calculations as needed; also discovered by the latter method were complexes (e.g., ion-dipole). Single-point energies were calculated at B3LYP/6-311+G(2d,p)// B3LYP-6-31G $(\mathrm{d}, \mathrm{p})$ level and scaled thermal-energy cor- rections for standard conditions were applied [41]. All calculated enthalpies are reported as relative to the initial protonated chalcone in $\mathrm{kJ} / \mathrm{mol}$.

\section{Experimental Results and Discussion}

\section{Chalcone (1)}

There are three major fragment ions in the CAD mass spectrum of the ESI-generated $[\mathrm{M}+\mathrm{H}]^{+}(\mathrm{m} / \mathrm{z} 209)$ of chalcone. The fragments form via elimination of $\mathrm{H}_{2} \mathrm{O}$, $\mathrm{CO}$, and $\mathrm{C}_{6} \mathrm{H}_{6}$ (presumably benzene) as reported earlier [19] along with minor fragments of $\mathrm{m} / \mathrm{z} 103, \mathrm{~m} / \mathrm{z} 105$, presumably benzoyl cation, and $\mathrm{m} / \mathrm{z}$ 194, from loss of the $\mathrm{CH}_{3}$ radical. A comparison of the CAD mass spectra of protonated chalcone and 3-phenylindanone (Table 1) reveals that both compounds give the same fragment ions (of $m / z$ 194, 191, 181, 131, and 103). For the 3-phenylindanone case, however, the abundances of ions at $\mathrm{m} / \mathrm{z} 191$ and 181 are greatly reduced, indicating that these fragments originate from another ionic species. In addition, the absence of the $m / z 105$ ion suggests that the benzoyl cation seen in the CAD mass spectrum of protonated chalcone represents that fraction of [M+ $\mathrm{H}]^{+}$ions that does not cyclize. Nevertheless, the overall commonality of fragmentation suggests that some fraction of protonated chalcone isomerizes via Nazarov cyclization to afford protonated 3-phenylindanone.

CA of the collision-generated $\mathrm{m} / \mathrm{z} 181$ ions $[\mathrm{M}+\mathrm{H}-$ $\mathrm{CO}]^{+}$via $\mathrm{MS}^{3}$ experiments (Table 2) affords three important fragment ions of $m / z 166,153$, and 103, which arise by elimination of $\mathrm{CH}_{3}, \mathrm{C}_{2} \mathrm{H}_{4}$, and $\mathrm{C}_{6} \mathrm{H}_{6}$, respectively. The CAD mass spectra of the $\mathrm{m} / \mathrm{z} 181$ fragment ions from protonated chalcone and 3-phenylindanone are similar, consistent with the proposed cyclization. In addition, CA of the $m / z 181$ ion obtained as [M+H -

Table 2. CAD mass spectra of the fragment ions of $\mathrm{m} / \mathrm{z} 181$

\begin{tabular}{lccccc}
\hline & \multicolumn{4}{c}{ Fragment ions: relative abundance } \\
\cline { 2 - 6 } Precursor of $m / z 181$ & $m / z 179$ & $m / z \quad 166$ & $m / z \quad 153$ & $m / z 103$ \\
\hline \hline Chalcone & 25 & 100 & 10 & 20 \\
3-Phenyl-1-indanone & 54 & 100 & 18 & 30 \\
1,1-Diphenylethanol & 8 & 100 & 14 & 16 \\
\hline
\end{tabular}


Table 3. Partial metastable-ion (MI) mass spectra of CI produced $[\mathrm{M}+\mathrm{H}]^{+}$ions

\begin{tabular}{crrrrr}
\hline & \multicolumn{4}{c}{ Fragment ions: relative abundance } \\
\cline { 2 - 6 } Compound number & $-\mathrm{H}_{2} \mathrm{O}$ & $-\mathrm{C}_{6} \mathrm{H}_{6}$ & $\begin{array}{c}- \text { Anisole } \\
\text { (-Phenolt) }\end{array}$ & $\begin{array}{c}- \text { Ketene } \\
\text { (-Methyl Ketene }\end{array}$ & Benzoyl $m / z$ 105 \\
\hline \hline $\mathbf{2}$ & 2 & 12 & 10 & 100 & 63 \\
$\mathbf{3}$ & 100 & $\mathrm{ND}$ & 10 & $* 26$ & 16 \\
$\mathbf{4}$ & 8 & 8 & 10 & ND & 100 \\
$\mathbf{5}$ & 4 & 50 & 22 & ND & 100 \\
$\mathbf{6}$ & 58 & 58 & ${ }^{+} 30$ & & 100 \\
\hline
\end{tabular}

$\left.\mathrm{H}_{2} \mathrm{O}\right]^{+}$from protonated 1,1-diphenyl ethanol (10), selected as a suitable reference, exhibits the same fragments. The similarities indicate that the $\left[\mathrm{M}+\mathrm{H}-\mathrm{CO}^{+}\right.$ fragment ions from both protonated chalcone and 3-phenylindanone possess the 1,1-diphenylethylcation structure, Table 2.

\section{2-Methoxychalcone (2)}

The ESI-generated $[\mathrm{M}+\mathrm{H}]^{+}$ion of 2-methoxy chalcone $(m / z 239)$ (2) fragments upon collisional activation to yield a dominant $m / z 197$ ion formed by elimination of $42 \mathrm{u}$ (Table 1). The accurate mass of the fragment ion, 197.0965, corresponds to $\mathrm{C}_{14} \mathrm{H}_{13} \mathrm{O}$ (calculated mass = 197.0966), indicating that the expelled neutral is $\mathrm{C}_{2} \mathrm{H}_{2} \mathrm{O}$, likely ketene. The dominant loss of ketene contrasts significantly with the fragmentations observed for protonated chalcone.

The metastable-ion (MI) decompositions of the CIgenerated $[\mathrm{M}+\mathrm{H}]^{+}$of $\mathbf{2}(\mathrm{m} / \mathrm{z} 239)$ (Table 3 ) yield $\mathrm{m} / \mathrm{z}$ 207, 197, 161, and 131 fragments formed by losses of methanol, ketene, and the elements of benzene and anisole, respectively. (Similar results were obtained for high-energy CAD of CI-generated $[\mathrm{M}+\mathrm{H}]^{+}$of 2.) We note that CI produces ions with greater internal energy than ESI, explaining the lack of $\mathrm{m} / \mathrm{z} 207,161$, and 131 fragments in the ESI low-energy CAD mass spectrum (Table 1) and indicating that these latter ions are formed by higher energy processes than that giving the $m / z 197$ ion, which is likely produced by a low-energy rearrangement. High-energy CAD of the $m / z 197$ fragment ion affords fragments ions at $m / z 181,165,152$, and 91 (Figure 1a). Given that the $m / z 91$ ion (benzyl or tropylium) corresponds to the base peak, the $\mathrm{m} / \mathrm{z} 197$ fragment must have a structure from which the $\mathrm{C}_{7} \mathrm{H}_{7}^{+}$ cation can be readily generated.

Furthermore, high-energy CAD of the $[\mathrm{M}+\mathrm{D}]^{+}$ion $(m / z 240)$ of Compound 2 generated by $\mathrm{CD}_{4} \mathrm{CI}$ shows that $[\mathrm{M}+\mathrm{D}]^{+}$dissociates by eliminating ketene rather than ketene- $d_{1},(m / z$ 198) indicating that the deuterium remains solely part of the product ion in the elimination of ketene. High-energy CA of the $\mathrm{m} / \mathrm{z} 197$ ion (Figure 1b) yields major fragments of $\mathrm{m} / \mathrm{z} 181$ (due to loss of $\mathrm{CH}_{4}$ ), 165 (loss of $\mathrm{CH}_{3} \mathrm{OH}$ ), and 91 (formation of $\mathrm{C}_{7} \mathrm{H}_{7}^{+}$), which are all shifted upward by one $m / z$ upon CA of the $m / z 198$ ion (Figure 1c). These results suggest that the initial D of $\mathrm{m} / \mathrm{z}$
240 has become one of the aromatic protons of the $m / z 198$ ion, specifically on the unsubstituted phenyl ring. We postulate that the likely structure of the $m / z 197$ ion is that of the 2-methoxyphenyl-phenyl-methyl cation and the $\mathrm{C}_{7} \mathrm{H}_{7}^{+}$is consequently the benzyl cation.
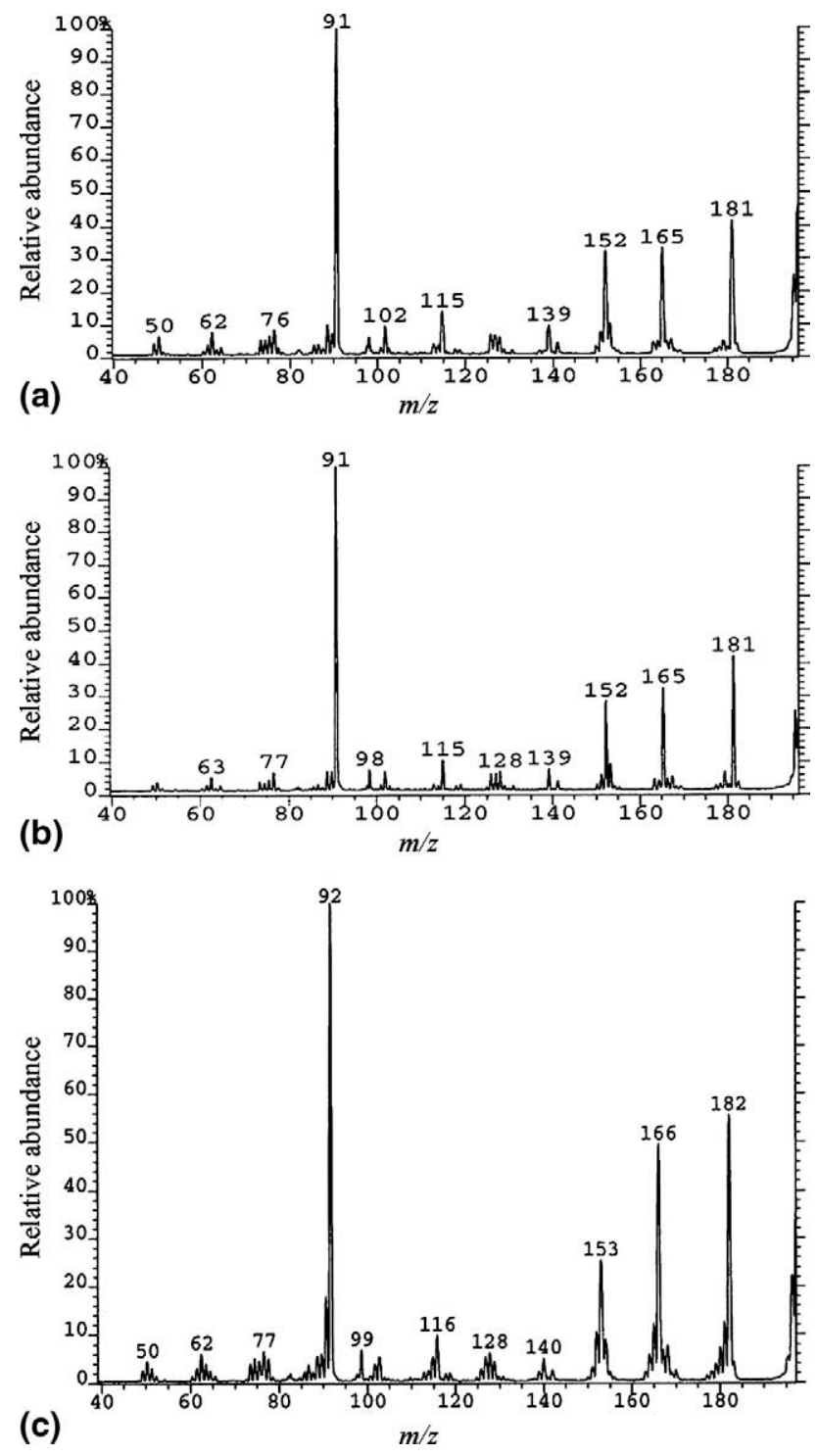

Figure 1. CAD mass spectra of (a) ion $\mathrm{m} / \mathrm{z} 197$ from 2 (b) $\mathrm{m} / \mathrm{z} 197$ ion from 3, (c) ion $\mathrm{m} / \mathrm{z} 198$ from $[\mathrm{M}+\mathrm{D}]^{+}$of 2 . Instrument: BEBE tandem sector. 

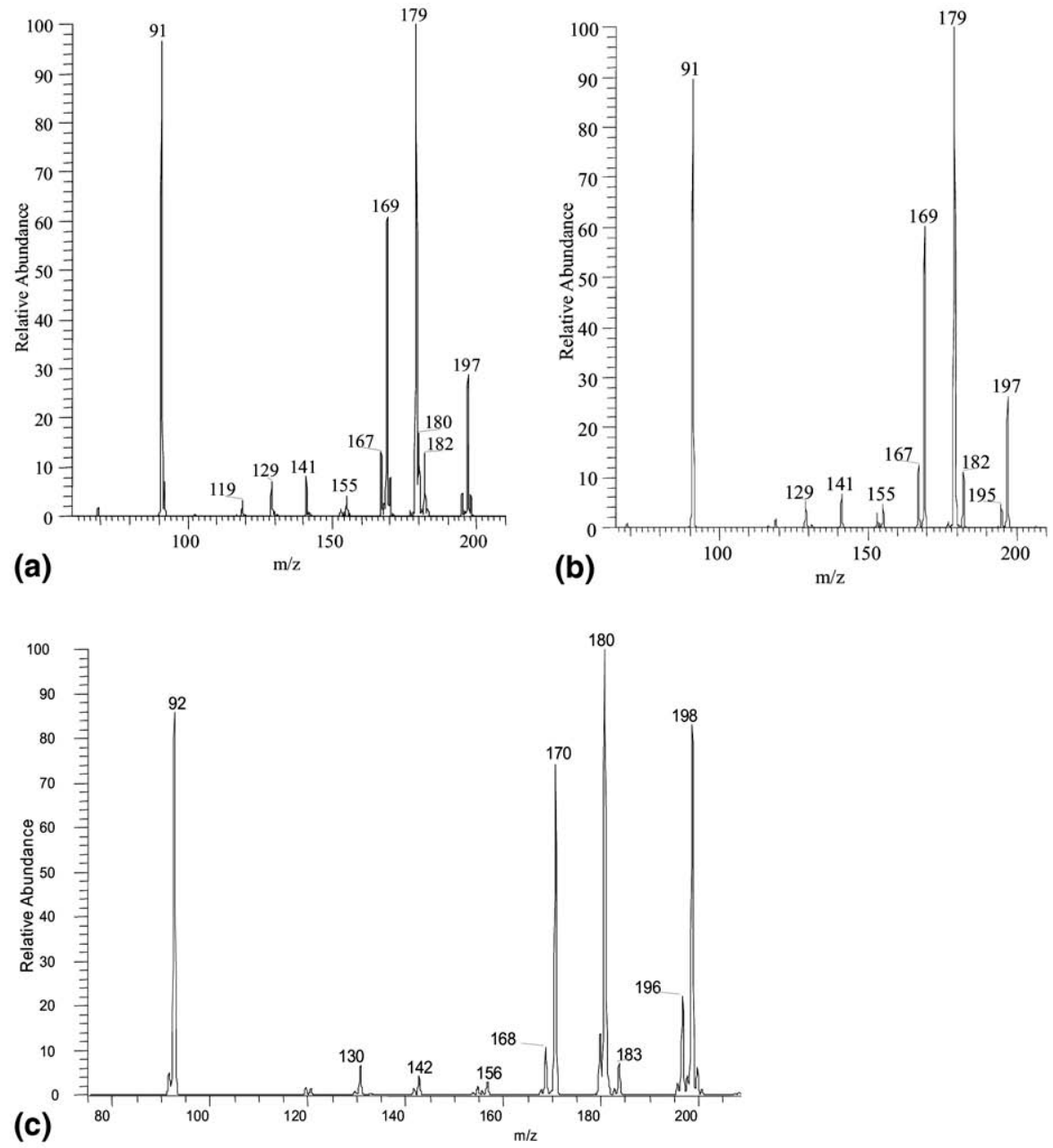

Figure 2. CAD mass spectra of (a) $m / z 197$ from 2-methoxy chalcone (2), (b) $m / z 197$ from 2-methoxybenzhydrol (8), (c) $\mathrm{m} / \mathrm{z} 198$ from $[\mathrm{M}+\mathrm{D}]^{+}$of $\mathbf{2}$. (All are $\mathrm{MS}^{3}$ experiments). Instrument: 3D ion trap.

We generated a suitable reference for the $\mathrm{m} / \mathrm{z} 197$ ion having the 2-methoxyphenyl-phenyl-methyl cation structure by low-energy CA of the ESI-generated [M + $\mathrm{Na}]^{+}$ion of 2-methoxybenzhydrol (8). Others have reported generating 2-methoxyphenyl-phenyl-methyl cation by loss of $\mathrm{H}_{2} \mathrm{O}$ from the CI-generated $[\mathrm{M}+\mathrm{H}]^{+}$ ion of $\mathbf{8}$ and producing its CAD mass spectrum via an ion trap instrument, which shows an abundant fragment of $\mathrm{m} / \mathrm{z} 91$ (benzyl cation) [42]. Furthermore, they reported an $\mathrm{C}_{7} \mathrm{H}_{5} \mathrm{D}_{2}^{+}$ion as a CAD fragment of the $\mathrm{OCD}_{3}$ analog $(\mathrm{m} / \mathrm{z} 200)$, derived by the loss of $\mathrm{H}_{2} \mathrm{O}$ from protonated $2-d_{3}$-methoxybenzhydrol, thus indicating that the methylene moiety of the benzyl cation is derived from the $\mathrm{OCH}_{3}$ group.

Low-energy CA (Figure 2a) of the collision-generated $\mathrm{m} / \mathrm{z} 197$ fragment via an $\mathrm{MS}^{3}$ experiment involving 2-methoxychalcone (2) compares well with that of the $\mathrm{m} / \mathrm{z} 197$ ion (MS ${ }^{3}$ experiment) from Compound 8 (Figure $2 \mathrm{~b}$ ). The strong similarity indicates that the $[\mathrm{M}+$ $\left.\mathrm{H}-\mathrm{CH}_{2} \mathrm{CO}\right]^{+}$ion from Compound 2 is the 2-methoxyphenyl-phenyl-methyl cation (eq 1). Low-energy CA in an MS $^{3}$ experiment involving the $m / z 197$ ion (Figure 2a) causes losses of $\mathrm{H}_{2} \mathrm{O}$ and $\mathrm{CO}$ (forming $\mathrm{m} / \mathrm{z} 179$ and 169 ions, respectively) and formation of the $\mathrm{m} / \mathrm{z} 91$ ion. The $\mathrm{m} / \mathrm{z}$ of these fragments increases by one for the $\mathrm{m} / \mathrm{z} 198$ intermediate $\left[\mathrm{M}+\mathrm{D}-\mathrm{CH}_{2} \mathrm{CO}\right]^{+}$(Figure 2c). Similar product-ion $\mathrm{m} / \mathrm{z}$ shifts occur upon high-energy CA of the CI-produced $\mathrm{m} / \mathrm{z} 198$ ion (Figure 1c). The facile losses of $\mathrm{H}_{2} \mathrm{O}$ and $\mathrm{CO}$ likely indicate substantial but low-energy rearrangement processes, whereas the losses of $\mathrm{CH}_{4}$ and $\mathrm{CH}_{3} \mathrm{OH}$ (Figure 1a) induced by high-energy MS/MS experiments are more direct, higher energy processes. In either case, the production of the $\mathrm{m} / \mathrm{z} 91$ ion is a dominant process exhibiting identical deuterium-labeling results.<smiles>COc1ccccc1/C=C/C(=O)c1cccc(C(=O)O)c1</smiles> 


\section{2-Methoxy- $\beta$-Methyl-Chalcone (3)}

We chose to examine the CAD mass spectrum of the ESI-produced $[\mathrm{M}+\mathrm{H}]^{+}$ion of $\beta$-methyl analogue, 2 -methoxy- $\beta$-methyl-chalcone (3) to determine the origin of the ketene. The $[\mathrm{M}+\mathrm{H}]^{+}$expectedly dissociates via elimination of methyl ketene to afford the $\mathrm{m} / \mathrm{z} 197$ ion (Table 1). Its accurate mass is 197.0964, in good agreement with the calculated mass of $[\mathrm{M}+\mathrm{H}-$ $\mathrm{CH}_{3} \mathrm{CH}=\mathrm{C}=\mathrm{O}^{+}$. The other major fragment ion is $\left[\mathrm{M}+\mathrm{H}-\mathrm{H}_{2} \mathrm{O}\right]^{+}$(measured mass, 235.1129; calculated for $\mathrm{C}_{17} \mathrm{H}_{15} \mathrm{O}, 235.1123$ ), which is likely facilitated by the protons on the $\beta$-methyl group.

The MI and high-energy CAD mass spectra of the CI-generated $[\mathrm{M}+\mathrm{H}]^{+}$of 3 (Table 3) exhibit peaks corresponding to $\mathrm{m} / \mathrm{z} 235,197$, and 145 ions, formed by expulsions of $\mathrm{H}_{2} \mathrm{O}$, methyl ketene $(56 \mathrm{u})$ and $\mathrm{CH}_{3} \mathrm{OC}_{6} \mathrm{H}_{5}$ $(108 \mathrm{u})$, respectively. Moreover, CA of the $\mathrm{m} / \mathrm{z} 197$ ion obtained by CI protonation of Compounds 2 and 3 (Figure 1a, b) gives similar results, indicating that the $\mathrm{m} / \mathrm{z} 197$ fragments from both compounds have the same structure, namely, the 2-methoxyphenyl(phenyl)methyl cation formed by similar reaction (eq 2). These observations indicate that the $[\mathrm{M}+\mathrm{H}]^{+}$of Compound 3 eliminates methylketene by a mechanism analogous to that for loss of ketene from protonated 2 and that the $\beta$ carbon along with the adjacent carbonyl group form the ketene core.

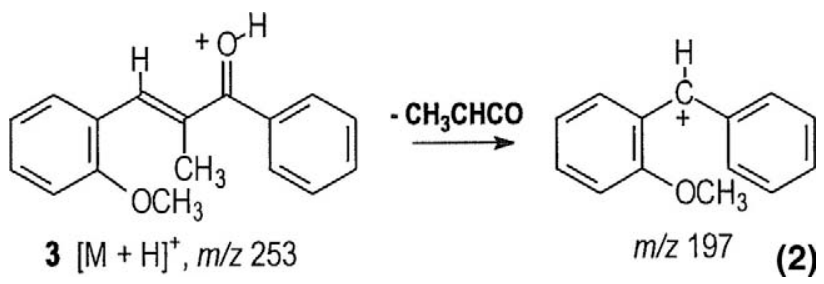

\section{2-Hydroxy-Chalcone (4)}

To delineate the role of methoxy in the elimination of ketene, we replaced the ortho $\mathrm{OCH}_{3}$ by $\mathrm{OH}$ and protonated the 2-hydroxy-chalcone by CI and ESI. The MI dissociations of the CI-generated $\left[\mathrm{M}+\mathrm{H}^{+}(\mathrm{m} / z 225)\right.$ are losses of $\mathrm{H}_{2} \mathrm{O}$, ketene, and $\mathrm{C}_{6} \mathrm{H}_{6}$ (giving $\mathrm{m} / z$ 207, 183, and 147 ions, respectively) (Table 3). CA of the ESIgenerated $[\mathrm{M}+\mathrm{H}]^{+}$(Table 1$)$ causes ketene elimination and formation of the benzoyl cation at $\mathrm{m} / \mathrm{z} 105$; the presence of the highly abundant $\mathrm{m} / \mathrm{z} 183$ ion and the absence of the $\mathrm{m} / \mathrm{z} 207$ and 147 ions suggest that loss of ketene is a lower energy process than losses of $\mathrm{H}_{2} \mathrm{O}$ and $\mathrm{C}_{6} \mathrm{H}_{6}$, as is also the case for 2-methoxy-chalcone (2).

By analogy to the structure of the $[\mathrm{M}+\mathrm{H}-$ $\left.\mathrm{CH}_{2} \mathrm{CO}\right]^{+}$fragment from 2-methoxy chalcone, we propose that the $\mathrm{m} / \mathrm{z} 183$ fragment is the 2-hydroxyphenylphenyl-methyl cation (eq 3). As a reference, we synthesized 2-hydroxybenzhydrol (9) that, upon protonation by ESI followed by CA, loses water to give the desired $\mathrm{m} / \mathrm{z} 183$ fragment. Low-energy CA of the ion from 6 (Figure 3a) and from its reference 9 (Figure 3b, Table 4)
$\mathrm{MS}^{3}$ gives similar spectra, indicating that the two $\mathrm{m} / \mathrm{z}$ 183 ions have the 2-hydroxyphenyl-phenyl-methyl cation structure [43]. Hence, the elimination of ketene from 4 follows a mechanism analogous to that for its elimination from 2, indicating that the $\mathrm{OH}$ group plays a nearly identical role as $\mathrm{OCH}_{3}$ in elimination of ketene.

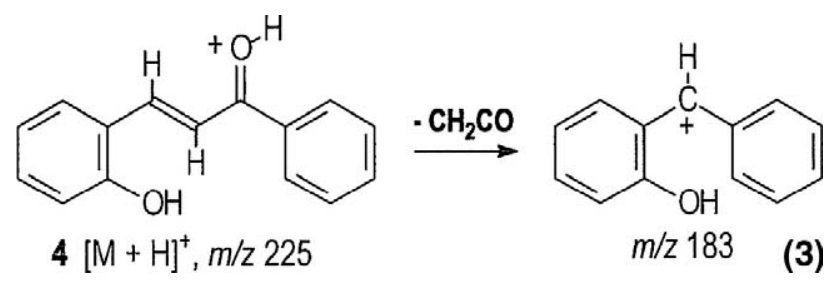

The $[\mathrm{M}+\mathrm{H}]^{+}$of 4 has two $\mathrm{OH}$ groups (assuming protonation on the carbonyl oxygen), and hence $\mathrm{H} / \mathrm{D}$ exchange/scrambling is possible in the corresponding $[\mathrm{M}+\mathrm{D}]^{+}$ion so that the $\mathrm{D}$ may be present as phenolic $\mathrm{OD}$ for some fraction of the $[\mathrm{M}+\mathrm{D}]^{+}$. Given that $\mathrm{H}^{+}$-shifts can be mediated by the oxygen atom of the phenolic group, both retention and loss of deuterium accompanying formation of the product ions are expected. High-energy CA of CI-generated $\left[\mathrm{M}+\mathrm{D}^{+}\right.$of $\mathrm{m} / \mathrm{z} 226$ from 4 does indeed produce $\mathrm{m} / \mathrm{z} 183$ and 184 ions in the abundance ratio of $\sim 1: 2$, confirming that $\mathrm{H} / \mathrm{D}$ exchange occurs and that both ketene and ketene- $d_{1}$ are eliminated. CA of ESI-generated [M $-\mathrm{H}+$ $2 \mathrm{D}]^{+}$ion of $m / z 227$ from 4 (Figure 4) gives $m / z$ 183, 184, and 185 ions owing to eliminations of ketene- $d_{2}$, ketene- $d$, and ketene in ratio of $\sim 1: 3: 1$, indicating $H / D$ scrambling before ketene elimination. The formation of ketene- $d_{2}$ along with the ratios of deuteria in the ketene elimination products indicate that, in addition to the two hydroxyl hydrogens, two other hydrogen are involved in scrambling. The proton of the ortho $\mathrm{OH}$ group must somehow initiate H/D scrambling, something that the otherwise similar ortho $\mathrm{OCH}_{3}$ (from 2) cannot.

In summary, protonated 2-methoxy (2) or 2hydroxychalcone (4) precursors decompose predominantly upon CA by ketene elimination to give 2-methoxy or 2-hydroxyphenyl-phenyl-methyl cations, respectively. This process requires a 1,3-migration or equivalent of the unsubstituted phenyl from the carbonyl carbon to the $\alpha$ carbon. Furthermore, the loss of methylketene from protonated 2-methoxy- $\beta$-chalcone (3) implies that the $\beta$-olefinic carbon, adjacent to the carbonyl group, is eliminated as part of the ketene in these systems. Finally, fragmentation of the $[\mathrm{M}+\mathrm{D}]^{+}$of (2) via ketene loss proceeds with complete retention of the $\mathrm{D}$ on the product $\mathrm{m} / \mathrm{z} 198$ ion, which fragments to yield benzyl ion $(\mathrm{m} / \mathrm{z}$ 92) also with $\mathbf{D}$ retention, implying that the initial D is transferred from the presumptive site of charging, the carbonyl oxygen, to an aryl site on the unsubstituted phenyl ' $\mathbf{b}$ ' ring. To accommodate these three mechanistic criteria, we propose that the protonated 2-methoxy and 2-hydroxy-chalcones undergo, upon activation, Nazarov cyclizations to give protonated 3-aryl-indanones from which ketene is eliminated 

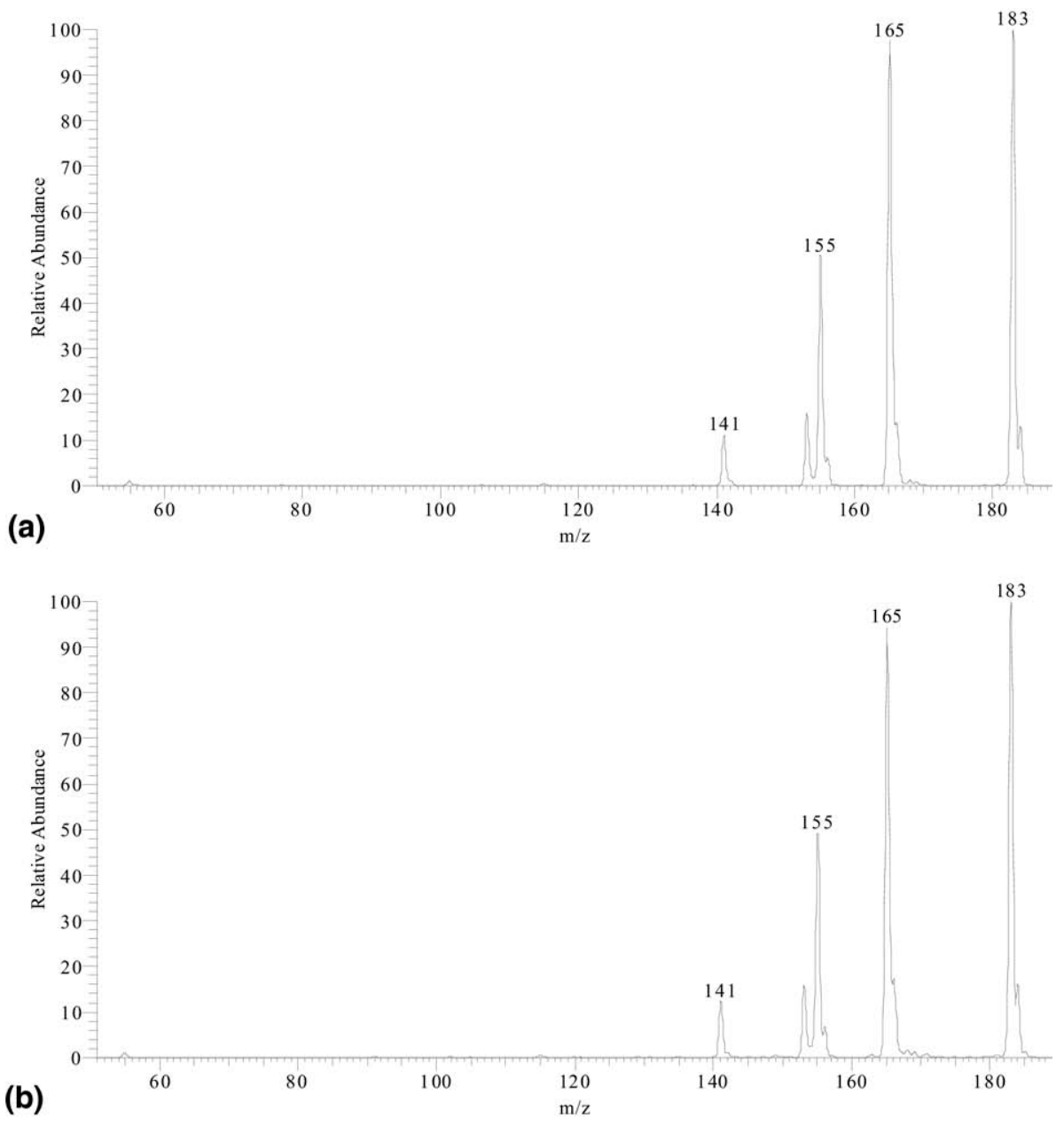

Figure 3. (a) The CAD MS of fragment ion of $\mathrm{m} / \mathrm{z} 183$ obtained by $\mathrm{MS}^{3}$ experiment on the ESI produced $[\mathrm{M}+\mathrm{H}]^{+}$of Compound 5. (b) The CAD MS of fragment ion of $\mathrm{m} / z 183$ obtained by $\mathrm{MS}^{3}$ experiment on the ESI produced $[\mathrm{M}+\mathrm{H}]^{+}$of Compound $\mathbf{1 1}$.

(eq 4). In addition, the 2-methoxy/2-hydroxy groups must play a crucial role for both the Nazarov cyclization and ketene loss because the unsubstituted chalcone, when protonated, gives only partial cyclization with no observable ketene loss.

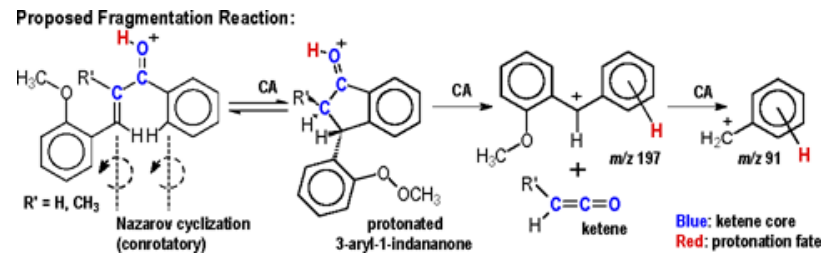

\section{2-Chlorochalcone (7)}

We designed a test for the hypothesis by investigating a chalcone with a less basic ortho substituent to delineate better the requirements for the cyclization and loss of ketene. CA of the $[\mathrm{M}+\mathrm{H}]^{+}$of 2-chlorochalcone shows that it fragments to yield $m / z 225,215,165$, and 131 ions by eliminations of $\mathrm{H}_{2} \mathrm{O}, \mathrm{CO}, \mathrm{C}_{6} \mathrm{H}_{6}$, and $\mathrm{C}_{6} \mathrm{H}_{5} \mathrm{Cl}$, respectively, analogous to the fragmentations of chalcone (Table 1). The $\mathrm{m} / \mathrm{z} 201$ fragment produced by ketene elimination, however, is only $2 \%$, indicating that the poorly basic $\mathrm{Cl}$ group is less capable than $\mathrm{OCH}_{3}$ and $\mathrm{OH}$ in catalyzing cyclization and ketene elimination.

Table 4. CAD mass spectra of collisionally generated ions of $\mathrm{m} / \mathrm{z} 183$

\begin{tabular}{lcccc}
\hline & \multicolumn{4}{c}{ Relative abundances of the fragment ions } \\
\cline { 2 - 5 } \multicolumn{1}{c}{ Precursor } & $m / z 165$ & $m / z 155$ & $m / z 153$ & $\mathrm{~m} / \mathrm{z} 141$ \\
\hline \hline 2-Hydroxychalcone (4) & 100 & 52 & 16 & 12 \\
2-Hydroxybenzhydrol (9) & 100 & 51 & 16 & 13 \\
\hline
\end{tabular}




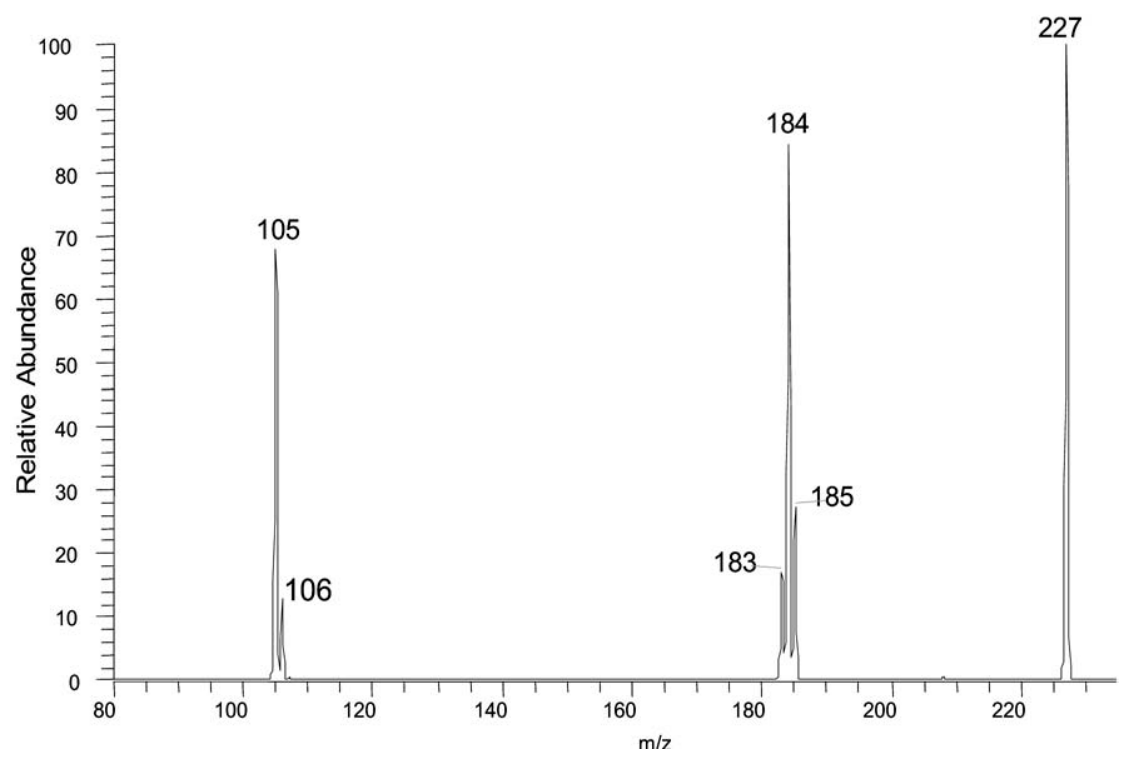

Figure 4. $\mathrm{CAD}$ mass spectrum of [2-hydroxychalcone $-\mathrm{OH}+2 \mathrm{D}]+$. Instrument: $3 \mathrm{D}$ ion trap.

Hence, there seems to be a minimum basicity requirement for the promotion of cyclization and the elimination of ketene. In addition, the low abundances of benzoyl cation $(4 \%)$ and of fragments arising from elimination of $\mathrm{H}_{2} \mathrm{O}$ or $\mathrm{CO}$ suggest that some fraction of the protonated 7 cyclizes by analogy to protonated chalcone.

\section{4-Methoxychalcone (5) and 4-Hydroxychalcone (6)}

To explore other criteria for cyclization, we examined 4-methoxychalcone (5) and 4-hydroxychalcone (6) using CI and ESI to protonate the neutral molecules. The MI dissociations of the CI-generated $[\mathrm{M}+\mathrm{H}]^{+}$ from $\mathbf{5}$ and $\mathbf{6}$ give rise to not only the benzoyl cation but also other fragments formed by eliminations of $\mathrm{H}_{2} \mathrm{O}, \mathrm{C}_{6} \mathrm{H}_{6}$, and substituted $\mathrm{C}_{6} \mathrm{H}_{6}$ analogous to eliminations from protonated unsubstituted chalcone; no detectable elimination of ketene occurs. CA of the ESI-produced $[\mathrm{M}+\mathrm{H}]^{+}$ions also produces benzoyl cations and other fragment ions formed by the eliminations of $\mathrm{H}_{2} \mathrm{O}, \mathrm{CO}$, and $\mathrm{C}_{6} \mathrm{H}_{6}$, and substituted $\mathrm{C}_{6} \mathrm{H}_{6}$ as established by accurate mass measurements (Table 5), but again no detectable elimination of ketene. By analogy to unsubstituted chalcone, a small fraction of protonated $\mathbf{5}$ and $\mathbf{6}$ may also cyclize to substituted indanones; the lower abundance of the benzoyl cation generated when ESI was used for protonation compared with when CI was used, and MI spectra taken (Table 1 and 3) indicates that cyclization takes place to a greater extent upon protonation by ESI. Overall, the results for protonated 5 and 6 relative to 2 and 4 clearly demonstrate the necessity of the ortho substitution for the promotion of Nazarov cyclization and subsequent elimination of ketene.

\section{Proposed Mechanisms and Theoretical Calculations}

\section{Theory: Protonated Chalcone}

We undertook theoretical calculations to aid in the elucidation of fragmentation mechanisms and the role of cyclization. Specific subjects are protonation, feasibility of cyclization, and subsequent fragmentation of protonated chalcone (1), 2-methoxy-chalcone (2), and 2-hydroxy-chalcone (9). Calculations reveal that the lowest-energy protonation of $[\mathrm{M}+\mathrm{H}]^{+}$ions occurs on carbonyl oxygen in all three cases. We chose these initial forms, $\mathbf{A}_{\mathbf{1}}$, as the reference points for calculat-

Table 5. Accurate masses of the fragment ions of Compounds 5 and $\mathbf{6}$

\begin{tabular}{cccccc}
\hline Compound & Nominal mass & Measured mass & Molecular formula & Calculated mass & Neutral lost \\
\hline \hline 4-Methoxy chalcone (5) & 221 & 221.0969 & $\mathrm{C}_{16} \mathrm{H}_{13} \mathrm{O}$ & 221.0966 & $\mathrm{H}_{2} \mathrm{O}$ \\
& 211 & 211.1141 & $\mathrm{C}_{15} \mathrm{H}_{15} \mathrm{O}$ & 211.1123 & $\mathrm{CO}$ \\
& 161 & 161.0601 & $\mathrm{C}_{10} \mathrm{H}_{9} \mathrm{O}_{2}$ & 161.0602 & $\mathrm{C}_{6} \mathrm{H}_{6}$ \\
& 207 & 207.0801 & $\mathrm{C}_{15} \mathrm{H}_{11} \mathrm{O}$ & 207.0809 & $\mathrm{H}_{2} \mathrm{O}$ \\
4-Hydroxy chalcone (6) & 197 & 197.0971 & $\mathrm{C}_{14} \mathrm{H}_{13} \mathrm{O}$ & 197.0966 & $\mathrm{CO}$ \\
& 147 & 147.0440 & $\mathrm{C}_{9} \mathrm{H}_{7} \mathrm{O}_{2}$ & 147.0445 & $\mathrm{C}_{6} \mathrm{H}_{6}$ \\
\hline
\end{tabular}


Table 6. Calculated relative enthalpies of formation/reaction (Scheme 1, in kJ/mol)

\begin{tabular}{|c|c|c|c|c|c|c|c|}
\hline Minima & Chalcone & $\begin{array}{l}\text { 2-Hydroxy } \\
\text { chalcone }\end{array}$ & $\begin{array}{l}\text { 2-Methoxy } \\
\text { chalcone }\end{array}$ & Transition states & Chalcone & $\begin{array}{l}\text { 2-Hydroxy } \\
\text { chalcone }\end{array}$ & $\begin{array}{l}\text { 2-Methoxy } \\
\text { chalcone }\end{array}$ \\
\hline Label & $\Delta^{2} H_{f}$ & $\Delta^{2} H_{f}$ & $\Delta^{2} H_{f}$ & Label & $\Delta^{2} H^{+}$ & $\Delta^{2} H^{+}$ & $\Delta^{2} H^{+}$ \\
\hline$A_{1}$ & 0 & 0 & 0 & TS $\left(A_{1}-A_{2}\right)$ & 140 & 129 & 120 \\
\hline$A_{2}$ & 21 & 23 & 22 & TS $\left(A_{2}-A_{3}\right)$ & 55 & 64 & 67 \\
\hline$A_{3}$ & 39 & 41 & 41 & $\operatorname{TS}\left(A_{3}-B_{1}\right)$ & 154 & 154 & 156 \\
\hline $\mathrm{A}_{4}$ & 3 & 4 & 4 & TS $\left(B_{1}-B_{2}\right)$ & 257 & 258 & 260 \\
\hline$A_{5}$ & & 3 & 4 & TS $\left(B_{2}-C_{3}\right)$ & 214 & 198 & 199 \\
\hline $\mathrm{B}_{1}$ & 123 & 131 & 134 & TS $\left(C_{3}-C_{6}\right)$ & 47 & 35 & 42 \\
\hline $\mathrm{B}_{2}$ & 194 & 195 & 191 & TS $\left(A_{1}-A_{4}\right)$ & 124 & 54 & 58 \\
\hline $\mathrm{C}_{1}$ & 116 & 121 & 125 & TS $\left(A_{4}-C_{1}\right)$ & 204 & 127 & 129 \\
\hline $\mathrm{C}_{2}$ & 116 & 133 & 130 & TS $\left(C_{1}-C_{2}\right)$ & 157 & 220 & 220 \\
\hline $\mathrm{C}_{3}$ & -10 & -3 & 1 & $\operatorname{TS}\left(C_{2}-C_{3}\right)$ & & 174 & 174 \\
\hline $\mathrm{C}_{4}$ & & 115 & 118 & TS $\left(A_{4}-A_{5}\right)$ & & 56 & 60 \\
\hline $\mathrm{C}_{5}$ & & 139 & 120 & TS $\left(A_{5}-C_{4}\right)$ & & 127 & 129 \\
\hline \multirow[t]{4}{*}{$\mathrm{C}_{6}$} & $=\mathrm{C}_{3}$ & -9 & -3 & TS $\left(C_{1}-C_{4}\right)$ & & 144 & 152 \\
\hline & & & & TS $\left(C_{4}-C_{5}\right)$ & & 138 & 128 \\
\hline & & & & TS $\left(C_{5}-C_{6}\right)$ & & 146 & 123 \\
\hline & & & & TS $\left(C_{5}-C_{6}\right) u$ & & 147 & \\
\hline
\end{tabular}

${ }^{\ddagger}$ The enthalpies of formation of the various transition structures.

ing relative enthalpies of formation and reaction in Tables 6 , and 7.

In addition to $\mathbf{A}_{\mathbf{1}}$, there is an ensemble of other uncyclized forms related by rotations about various bonds between the two phenyl rings and by proton transfers ( $\mathbf{A}_{\mathbf{i}}$ of the Schemes). The formation of protonated 3-aryl-1-indanones from these precursors via Nazarov cyclization in the gas phase would require the equivalent of a $1,3-\mathrm{H}^{+}$transfer after the conrotatory cyclization. We could not find this transition state and, even if it did exist, it probably would require substantial energy to cross such that other processes would predominate. As shown on Scheme 1, there are three other routes (Figure 5) to accomplish that equivalent of this H-transfer. Route $\mathbf{1}, \mathbf{A}_{\mathbf{1}} \rightarrow \mathbf{A}_{\mathbf{2}} \rightarrow \mathbf{A}_{\mathbf{3}} \rightarrow \mathbf{B}_{\mathbf{1}} \rightarrow \mathbf{B}_{\mathbf{2}} \rightarrow$ $\mathrm{C}_{3} \rightarrow \mathrm{C}_{6}$, involves a pair of $1,2-\mathrm{H}^{+}$transfers, however, the transition-state $\mathbf{T S}\left(\mathbf{B}_{\mathbf{1}}-\mathbf{B}_{\mathbf{2}}\right)$ still requires $>250 \mathrm{~kJ} / \mathrm{mol}$ additional energy to surmount (Table 6). On Route 2, $\mathrm{A}_{1} \rightarrow \mathrm{A}_{4} \rightarrow \mathrm{C}_{1} \rightarrow \mathrm{C}_{2} \rightarrow \mathrm{C}_{3} \rightarrow \mathrm{C}_{6}$, which requires a pair of $1,4-\mathrm{H}^{+}$transfers, the greatest barrier is transitionstate $\mathbf{T S}\left(\mathbf{C}_{1}-\mathbf{C}_{2}\right)$, which requires 200 to $220 \mathrm{~kJ} / \mathrm{mol}$ additional energy. Route $3, \mathbf{A}_{1} \rightarrow \mathbf{A}_{4} \rightarrow \mathbf{A}_{5} \rightarrow \mathbf{C}_{4} \rightarrow$ $\mathrm{C}_{5} \rightarrow \mathrm{C}_{6}$, requires a pair of favorable $1,5-\mathrm{H}^{+}$transfers involving the ortho substituent and, in contrast, presents maximum barriers on trajectory from $\mathbf{A}_{5}$ to $\mathbf{C}_{6}$ that require $<160 \mathrm{~kJ} / \mathrm{mol}$ additional energy. In addition, calculations reveal that the protonated 3-aryl-1indanones are the most stable structures on the potential energy surface from protonated chalcones to the elimination of ketene.

Route 3 , the most favorable route through cyclization to the protonated 3-aryl-1-indanones (Figure 5 illustrating 2-methyoxychalcone case), constitutes an example of intramolecular proton-catalyzed transport [21-24] where the transport mediator is the oxygen of the 2-hydroxy or 2-methoxy groups. Since Route 3 in not available for the unsubstituted chalcone case, conversion to protonated 3-aryl-1-indanone then would be by

Table 7. Calculated relative enthalpies of formation and reaction (Scheme 2, in $\mathrm{kJ} / \mathrm{mol}$ )

\begin{tabular}{|c|c|c|c|c|c|c|c|}
\hline Minima & Chalcone & $\begin{array}{c}\text { 2-Hydroxy } \\
\text { chalcone }\end{array}$ & $\begin{array}{c}\text { 2-Methoxy } \\
\text { chalcone }\end{array}$ & Transition states & Chalcone & $\begin{array}{l}\text { 2-Hydroxy } \\
\text { chalcone }\end{array}$ & $\begin{array}{c}\text { 2-Methoxy } \\
\text { chalcone }\end{array}$ \\
\hline Label & $\Delta^{2} H_{f}$ & $\Delta^{2} H_{f}$ & $\Delta^{2} H_{f}$ & Label & $\Delta^{2} H^{\ddagger}$ & $\Delta^{2} H^{+}$ & $\Delta^{2} H^{+}$ \\
\hline $\mathrm{C}_{7}$ & & 119 & 98 & TS $\left(C_{6}-C_{7}\right)$ & & 122 & 103 \\
\hline $\mathrm{C}_{8}$ & -6 & -5 & 1 & $\mathrm{TS}\left(\mathrm{C}_{7}-\mathrm{G}_{1}\right)$ & & 133 & 126 \\
\hline $\mathrm{C}_{9}$ & 118 & 119 & 124 & TS $\left(C_{6}-C_{8}\right)$ & 41 & 42 & 47 \\
\hline $\mathrm{G}_{1}$ & 124 & 117 & 121 & TS $\left(C_{8}-C_{9}\right)$ & 214 & 213 & 217 \\
\hline $\mathrm{G}_{2}$ & 113 & 115 & 119 & TS $\left(C_{9}-G_{1}\right)$ & 173 & 169 & 175 \\
\hline $\mathrm{G}_{3}$ & & 111 & 97 & $\mathrm{TS}\left(\mathrm{G}_{1}-\mathrm{G}_{2}\right)$ & 127 & 126 & 132 \\
\hline \multirow[t]{3}{*}{$\mathrm{IDC}_{\mathrm{K}}$} & 102 & 112 & 115 & $\mathrm{TS}\left(\mathrm{G}_{2}-\mathrm{G}_{3}\right)$ & & 121 & 126 \\
\hline & & & & $\mathrm{TS}\left(\mathrm{G}_{3}-\mathrm{H}_{1}\right)$ & & 141 & 142 \\
\hline & & & & $\mathrm{TS}\left(\mathrm{G}_{2}-\mathrm{H}_{1}\right)$ & 137 & 142 & 144 \\
\hline Label & $\Delta^{2} H_{r x}$ & $\Delta^{2} H_{r x}$ & $\Delta^{2} H_{r x}$ & & & & \\
\hline $\mathrm{H}_{1}+\mathrm{K}$ & 117 & 126 & 124 & & & & \\
\hline
\end{tabular}

FThe enthalpies of formation of the various transition structures. 


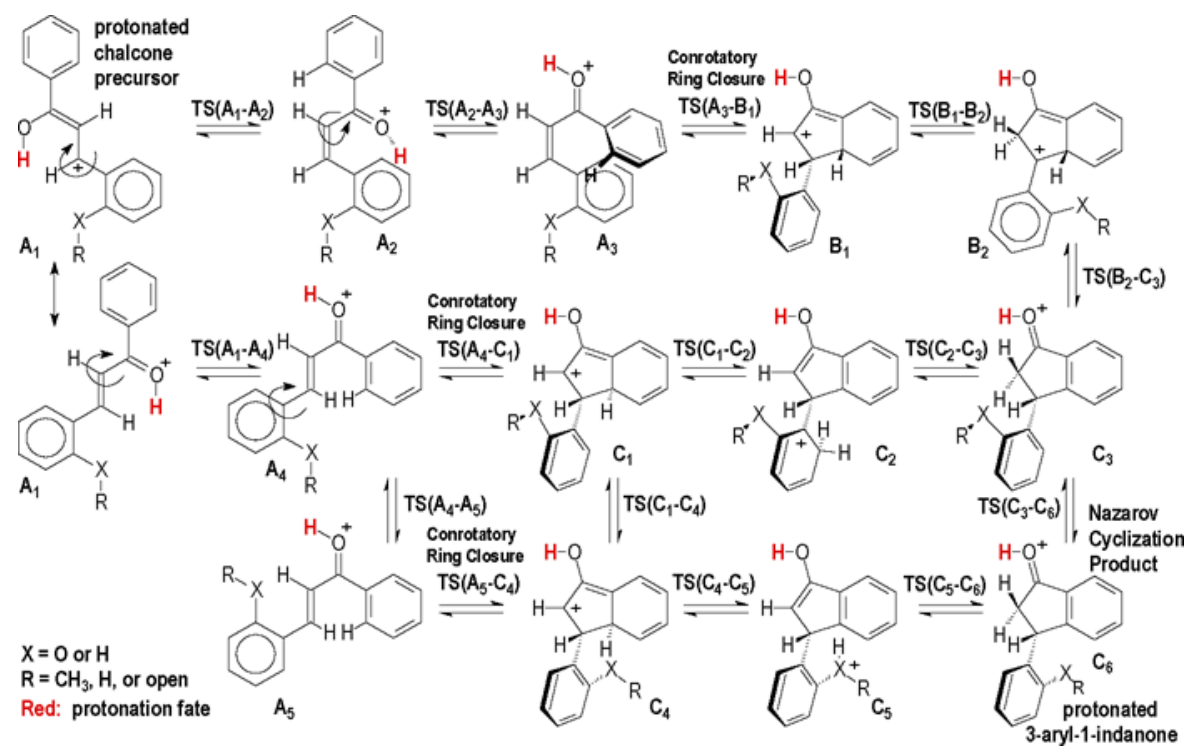

Scheme 1. Proposed mechanism, formation of protonated 3-aryl-indanone from protonated chalcone precursor.

Route 2 requiring $204 \mathrm{~kJ} / \mathrm{mol}$, hence cyclization for the unsubstituted chalcone would be less competitive and only partially complete, as observed experimentally. The most favorable Route 3 would also not be available for the 4-hydoxy and 4-methoxy isomers for geometric reasons, explaining why these isomers exhibit similar fragmentation features as the unsubstituted chalcone. A critical requirement for intramolecular protoncatalyzed transport of Route 3 is the presence of an ortho substituent of sufficient basicity to abstract a proton from the $\mathrm{C} 9$ (former $\mathrm{C}^{\prime}$ ) position for subsequent transfer to the $\mathrm{C} 2$ (former $\beta$ ) position. The calculated relative enthalpies of formation for $\mathrm{C}_{4}, \mathrm{C}_{5}$, and connecting transition-state $\left.\mathrm{TS}_{(} \mathrm{C}_{4}-\mathrm{C}_{5}\right)$ show additional investment $<25 \mathrm{~kJ} / \mathrm{mol}$ to accomplish a feasible proton transfer to the 2-hydroxy and 2-methoxy moieties (Ta-

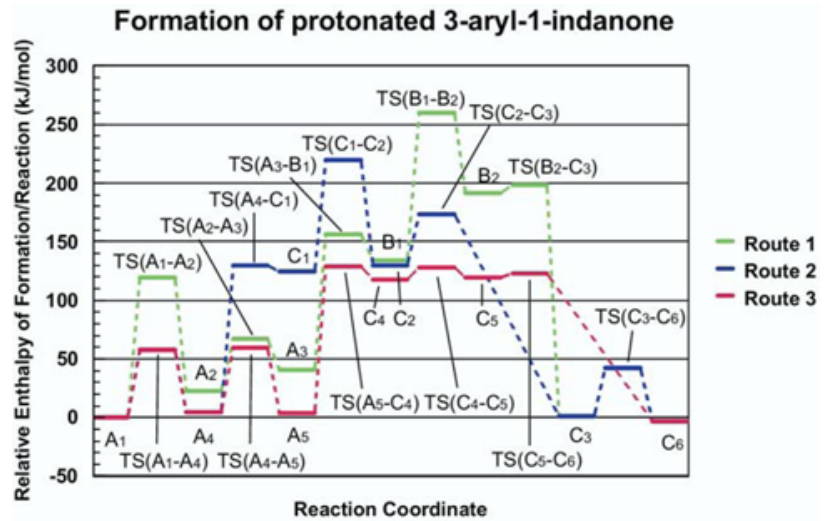

Figure 5. Comparative enthalpies of formation along reaction routes to protonated 3-aryl indanone formation (2-methyoxychalcone case). ble 6). In contrast, $\mathbf{C}_{5}$ for the 2-chloro substituent is not stable, and thus would be less efficient as an agent for proton-catalyzed transport [22].

The elimination of ketene from the protonated 3aryl-1-indanones [e.g., from (2) and (4)], requires the translocation of the proton on the carbonyl oxygen to somewhere on the phenyl ring (former ' $\mathbf{b}$ ' ring), as required by the $\mathrm{D}$ labeling results, particularly in the 2-methoxy case (2) where no $d_{1}$-ketene loss occurs. Two routes are available (Scheme 2, Figure 6). Route A involves transfer of proton from the carbonyl oxygen to $\mathrm{C} 7$ and then to $\mathrm{C} 8, \mathrm{C}_{6} \rightarrow \mathrm{C}_{8} \rightarrow \mathrm{C}_{9} \rightarrow \mathrm{G}_{1}$ where $\mathrm{TS}\left(\mathrm{C}_{8}-\mathrm{C}_{9}\right)$ requires $>210 \mathrm{~kJ} / \mathrm{mol}$ additional energy to surmount. In contrast, route $B, \mathbf{C}_{6} \rightarrow \mathbf{C}_{7} \rightarrow \mathrm{G}_{1}$ presents a maximum barrier of ${ }^{\prime} \sim 130 \mathrm{~kJ} / \mathrm{mol}$ to same intermediate $\left(\mathbf{G}_{\mathbf{1}}\right)$. On route $\mathbf{B}$, the $\mathrm{OCH}_{3}$, and $\mathrm{OH}$ groups act as intramolecular proton transfer catalysts; the ionizing $\mathrm{H}^{+}$on the carbonyl group is first abstracted to the 2-methoxy or 2-hydroxyl group and then transferred to the $\mathrm{C} 8$ position (former $\mathrm{C}^{\prime}$ ' on the ' $\mathbf{b}$ ' ring), activating the adjacent $\mathrm{C}-\mathrm{C}$ bond for cleavage to $\mathrm{G}_{2}$. The basicity of the ortho $\mathrm{OCH}_{3}$ and $\mathrm{OH}$ groups is necessary for efficient proton transfer catalysis (Table 7), something that an ortho $\mathrm{Cl}$ cannot perform because corresponding intermediate $\mathbf{C}_{7}$ is unstable. From $\mathbf{G}_{2}$ are two energetically similar paths, one direct and another through a cyclic intermediate $\mathbf{G}_{3}$, resulting in formation an ion-dipole complex, IDC $_{\mathbf{K}}$, preparatory to elimination of ketene. The ionizing proton thus is translocated to the ortho position of the unsubstituted phenyl group in the product ion $\mathbf{H}_{1}$, in accord with $\mathrm{D}^{+}$labeling results The ketene loss via proton transport catalysis is so facile that it suppresses any other fragmentations routes for the protonated 3-(2methoxy) phenyl-1-indanone intermediate, whereas 


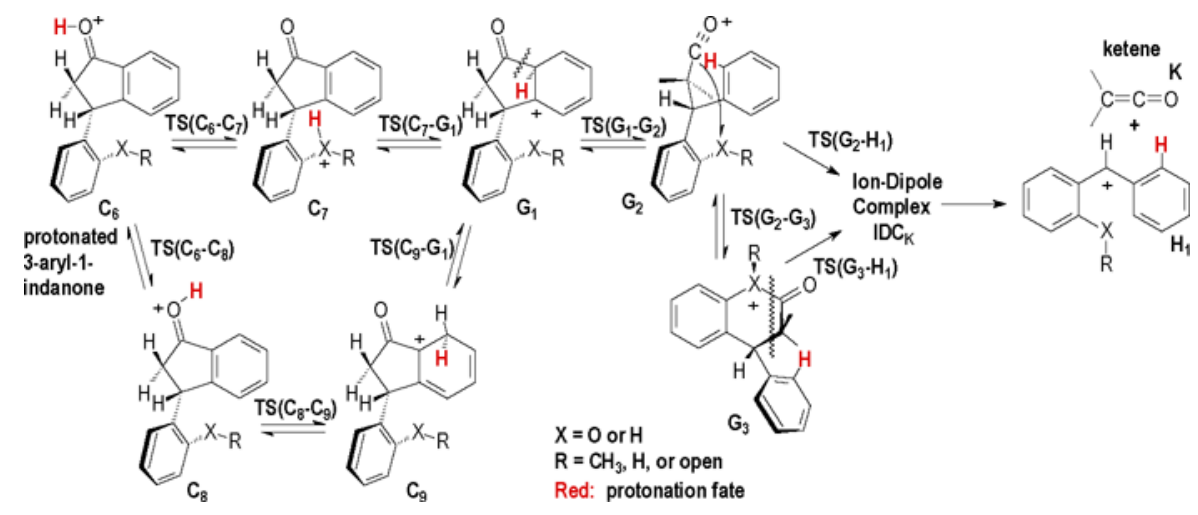

Scheme 2. Proposed mechanism, elimination of ketene from protonated 3-aryl-1-indanone.

ketene loss is not observed for protonated 3-phenyl1 -indanone.

The 2-hydroxy analog (4) differs from the 2-methoxy case in several important ways. First, there is a much greater abundance of the $m / z 105$ ion in the ESI CAD mass spectrum of 4 (Table 1) compared with that of 2-methoxychalcone under identical conditions (same instrument and collision energy). Second, H/D scrambling occurs in both high-energy CAD of the CIproduced $[\mathrm{M}+\mathrm{D}]^{+}$and low-energy $\mathrm{CAD}$ of the ESI-produced $[\mathrm{M}-\mathrm{H}+2 \mathrm{D}]^{+}$whereas no $\mathrm{H} / \mathrm{D}$ exchange is detectable for the 2-methoxy analogue (2). We rationalize these differences by a proposed mechanism (Scheme 3) whereby the protons of the 2-OH groups and the $\beta-\mathrm{C}-\mathrm{H}$ site are interchanged becoming equivalent with regard to $H / D$ labeling. This interchange is initiated by the phenol $\mathrm{OH}$, which is not possible for the 2-methoxy analogue. A fourth proton, at C2' of the ' $\mathbf{b}$ ' ring (C9 after cyclization), becomes involved in that both protons on the $\mathrm{R}-\mathrm{OH}_{2}^{+}$moiety of intermediate $\mathrm{C} 5$ (Scheme 1) can be transferred to the $\mathrm{C} 6$ site (former $\beta-\mathrm{C}$ ) by virtually equal barriers, $\mathbf{T S}\left(\mathbf{C}_{5}-C_{6}\right)$ versus $\mathbf{T S}\left(\mathbf{C}_{5}-\right.$ $\left.\mathrm{C}_{6}\right) \mathbf{u}$ (Table 6). This process is also unavailable to the 2-methoxy analogue. The resulting H/D distribution would be 1:2 for $d_{1} / d_{0}$-ketene elimination from [M +

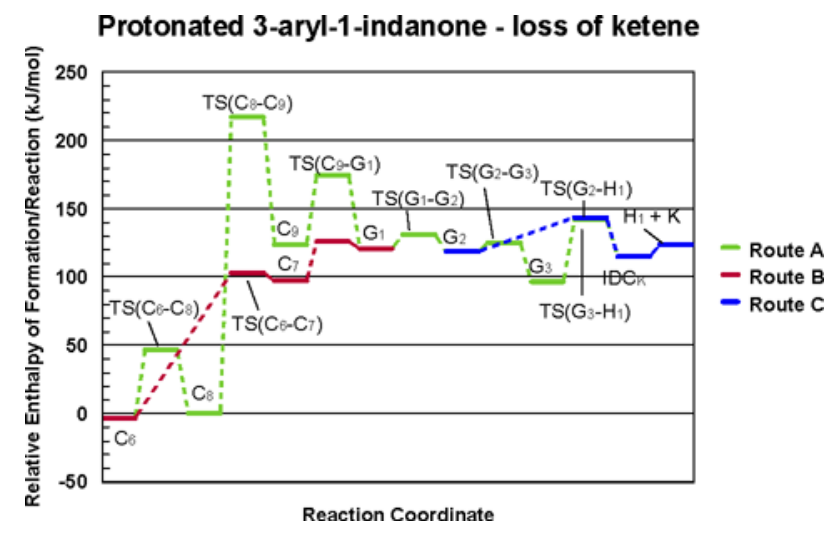

Figure 6. Comparative enthalpies of formation/reaction of ketene elimination from protonated 3-aryl indanone (2-methoxychalcone case).
$\mathrm{D}]^{+}$, as is observed, and 1:4:1 for $d_{2} / d_{1} / d_{0}$-ketene from $[\mathrm{M}-\mathrm{H}+2 \mathrm{D}]^{+}$, which is close to the experimental $\sim$ 1:3:1. Thus, the labeling results provide strong confirmation for the proposed mechanisms. In addition, generation of $m / z 105$, the benzoyl cation, is accomplished by direct cleavage of $\mathbf{A}_{\mathbf{8}}$ with no reverse activation barrier.

Another type of cyclization is possible where the protonated carbonyl initiates an electrophilic attack upon the 'a' ring (Scheme 4). The cyclic products thus generated are configured for ready elimination of $\mathrm{H}_{2} \mathrm{O}$. This route of elimination, however, requires greater energy than that for ketene elimination and appears to be competitive only for those compounds that do not have an ortho substituent to catalyze critical proton-catalyzed transports.

From the $[\mathrm{M}+\mathrm{D}]^{+}$of 2-methyoxy-chalcone (2), the quantitative formation of the $\mathrm{m} / \mathrm{z} 92$ versus $\mathrm{m} / \mathrm{z} 91$ (Figure 2c) product ion from the collision-generated $\mathrm{m} / \mathrm{z}$ 198 ion $\left[\mathrm{M}+\mathrm{D}-\mathrm{CH}_{2} \mathrm{CO}\right]^{+}$clearly substantiates that $\mathrm{D}$ is present in the phenyl ring of $\mathrm{m} / \mathrm{z}$ 198. This reaction belongs to the class of empirically-observed fragmentations from substituted diphenylcarbinols and diphenylmethyl cations $[42,43]$. We have verified the basic postulated mechanism by theoretical calculations; the $\mathrm{m} / \mathrm{z} 197$ ion decomposes to give the $m / z 91$ ion benzyl cation formed by the mechanism in Scheme 5 . An addition to the original proposed mechanism revealed by theoretical calculations is the formation of an ion-dipole complex, IDC $_{\mathbf{Q}}$, in the fragmentation exit channel to products. The mechanism preserves the location of the charging proton at the ortho position of the unsubstituted phenyl ring where it is remote to exchange reactions.

Further information regarding the theoretical calculations is available in the Supplementary Materials.

\section{Conclusions}

Although a Nazarov-type cyclization likely occurs to some extent for protonated chalcone, this process becomes of high yield for the protonated 2-hydroxy and 2-methoxy chalcones (Scheme 1). The intermediate products are protonated 3-aryl-1-indanones. A key finding is that $\mathrm{OCH}_{3}$ and $\mathrm{OH}$ groups at the ortho position act as proton-transfer catalysts, in that they 


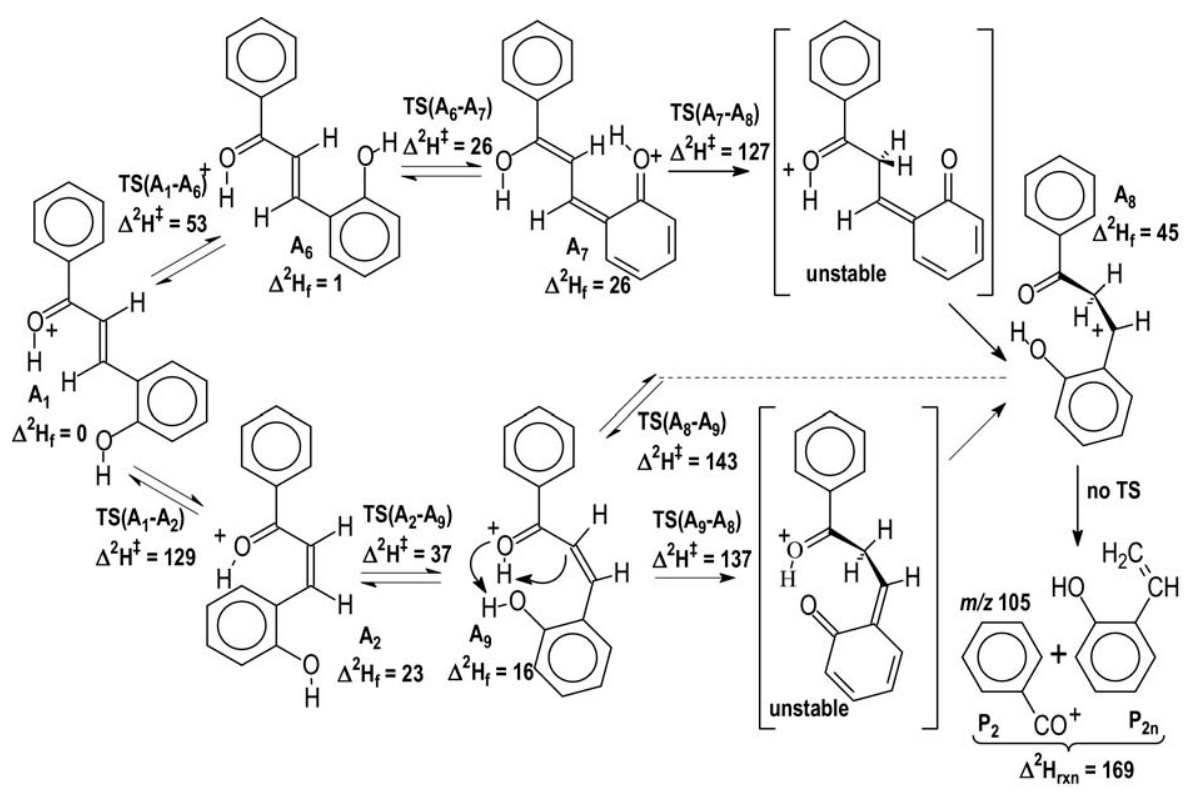

Scheme 3. Proposed mechanism involved in H/D scrambling in protonated 2-hydroxychalcone.

decrease the activation energy for the equivalent 1,3 proton shift, a key step. Subsequently, ketene elimination occurs by a second, key 1,3 proton-shift (Scheme 2) similarly catalyzed by the oxygen atom of the ortho $\mathrm{OCH}_{3}$ or $\mathrm{OH}$ groups. When the $\mathrm{OCH}_{3}$ or $\mathrm{OH}$ groups, however, are absent from the ortho position, Nazarovtype cyclization takes place to a significantly lesser extent, and must compete with another type of cyclization. In addition, competitive expulsions of $\mathrm{CO}, \mathrm{H}_{2} \mathrm{O}$, and $\mathrm{C}_{6} \mathrm{H}_{6}$ (or substituted $\mathrm{C}_{6} \mathrm{H}_{6}$ ) take place instead of ketene, which are also characteristic of protonated 3-phenyl-1-indanone. The structures of the $[\mathrm{M}+\mathrm{H}-$ ketene $]^{+}$and $[\mathrm{M}+\mathrm{H}-\mathrm{CO}]^{+}$, as determined by comparison of their CAD mass spectra with those of reference ions, are consistent with these hypotheses. The proposed mechanisms find strong support from theoretical calculations using density functional theory and from accurate-mass data, tandem mass spectrometric experiments, and deuterium-labeling.

The gas-phase Nazarov cyclization of protonated chalcones is analogous to that occurring in solution. Its extent in the gas phase depends on the method used to protonate the starting material and on the nature and position of substituents. Moreover, the study shows that the cyclization and fragmentation of 2-methoxy and 2-hydroxy-chalocone are examples of intramolecular proton-transport catalysis.

\section{Acknowledgments}

V.S.S. and M.G. thank the KSCSTE for financial assistance, and Principal, Sacred Heart College, Thevara for providing infrastructure. R.S. thanks Dr. J. S. Yadav, Director, IICT, Hyder-

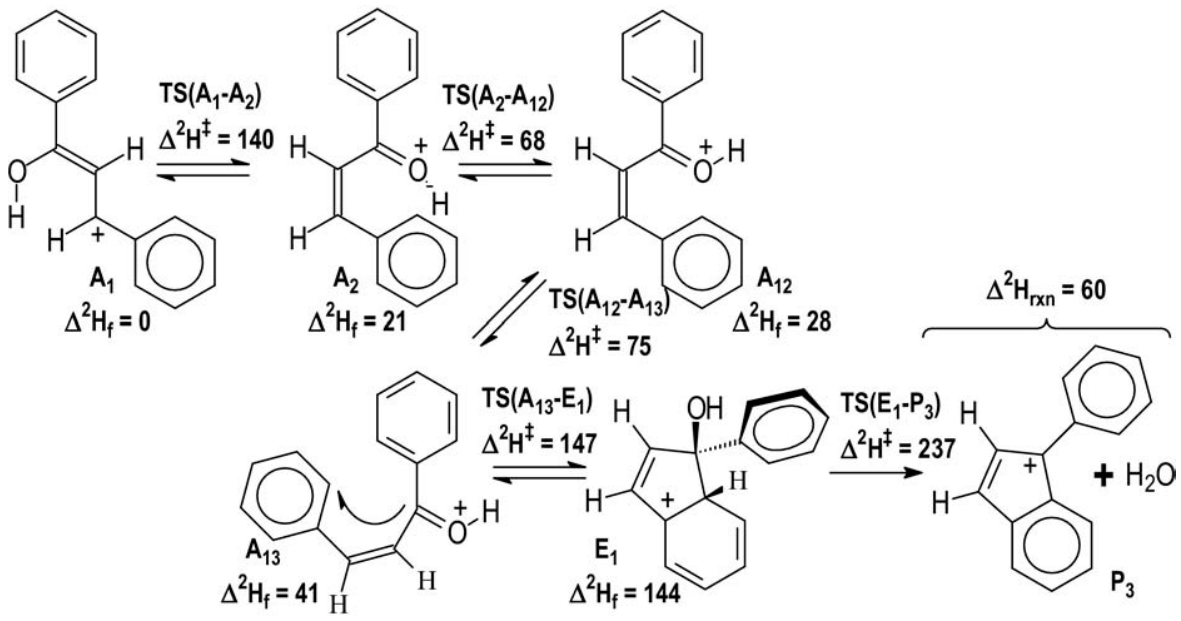

Scheme 4. Proposed alternate cyclization of protonated chalcone (1). 


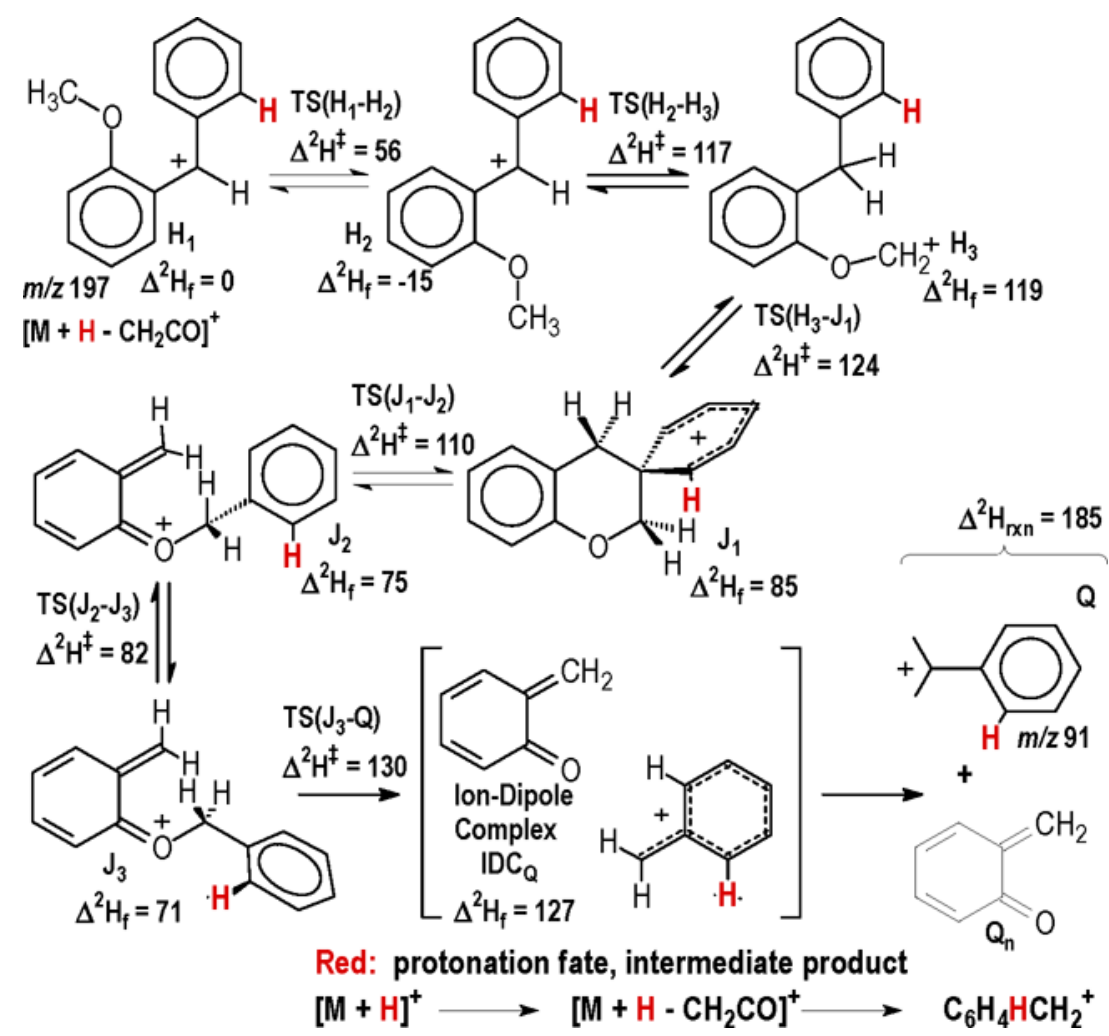

Scheme 5. Proposed mechanism, from $\mathrm{m} / \mathrm{z} 197$ to $\mathrm{m} / \mathrm{z} 91$ [42, 43]. Calculated enthalpies reported relative to $\mathbf{H}_{\mathbf{1}}$ in $\mathrm{kJ} / \mathrm{mol}$.

abad, for facilities and Dr. M. Vairamani for cooperation. Research at WU was supported by the National Centers for Research Resources of the NIH, grant P41RR00954. In addition, this work made use of the Washington University Computational Chemistry Facility, supported by NSF grant CHE0443501

\section{Appendix A \\ Supplementary Material}

Supplementary material associated with this article may be found in the online version at doi:10.1016/j.jasms. 2008.12.017.

\section{References}

1. Pellissier, H. Recent Developments in the Nazarov Process. Tetrahedron 2005, 61, 6479-6517.

2. Frontier, A.; Collinson, C. The Nazarov Cyclization in Organic Synthesis. Recent advances. Tetrahedron 2005, 61, 7577-7606.

3. Gu, X. H.; Yu, H.; Jacoboson, A. E.; Rothman, R. B.; Dersch, C. M.; George, C.; Flippen-Anderson, J. L.; Rice, K. C. Design, Synthesis, and Monoamine Transporter Binding Site Affinities of Methoxy Derivatives of Indatraline. J. Med. Chem. 2000, 43, 4868-4876.

4. Elliott, J. D.; Lago, M. A.; Cousins, R. D.; Leber, J. D.; Erhard, K. F.; Nambi, P.; Elshourbagy, M. A.; Kumar, C.; Lee, J. A.; Bean, J. W.; DeBrosse, C. W.; Eggleston, D. S.; Brooks, D. P.; Geuerstein, G.; Ruffolo, R. R. Jr.; Weinstock, J.; Gleason, J. G.; Peishoff, C. E.; Ohlstein, E. H. 1,3-Diarylindan-2-Carboxylic Acids, Potent and Selective Non-Peptide Endothelin Receptor Antagonists. J. Med. Chem. 1994, 37, 1553-1557.

5. Lawrence, N. J.; Simon, E.; Armitage, M.; Greedy, B.; Cook, D.; Ducki, S.; McGown, A. T. The Synthesis of Indanones Related to Combretastatin A-4 Via Microwave-Assisted Nazarov Cyclization of Chalcones. Tetrahedron Lett. 2006, 47, 1637-1640.

6. Yin, W.; Ma, Y.; Xu, J.; Zhao, Y. Microwave-Assisted One-Pot Synthesis of 1-Indanones from Arenes and $\alpha, \beta$-Unsaturated Acyl Chlorides. I. Org. Chem. 2006, 71, 4312-4315.
7. Sivakumar, P. M.; Seenivasan, S. P.; Kumar, V.; Doble, M. Synthesis, Antimycobacterial Activity Evaluation, and QSAR Studies of Chalcone Derivatives. Bioorg. Med. Chem. Lett. 2007, 17(6), 1695-1700.

8. Beynon, J. H.; Lester, G. R.; Williams, A. E. Specific Molecular Rearrangements in the Mass Spectra of Organic Compounds. J. Phy. Chem. 1959, 63, 1861-1868.

9. Van De Sande, C.; Serum, J.; Vandwalle, W. Organic Mass Spectrometry. XII. Mass Spectra of Chalcones and Flavanones. Isomerization of 2'-Hydroxychalcone and Flavanone. Org. Mass Spectrom. 1972, 6, 1333 1346.

10. Ronayne, J.; Williams, D. H.; Bowie, J. H. Mass Spectrometry. XIX Evidence for the Occurrence of Aromatic Substitution Reactions Upon Electron Impact. J. Am. Chem. Soc. 1966, 88, 4980-4984.

11. Rouvier, E.; Medina, H.; Cambon, A. Mass Spectrometric Studies. VIII Fragmentation of Several Benzalacetophenones and Benzalacetones Variously Substituted on the Aromatic Ring. Org. Mass Spectrom. 1976, 11, 800-813.

12. Schaldach, B.; Grutzmacher, H. F. The Fragmentations of Substituted Cinnamic Acids After Electron Impact. Org. Mass Spectrom. 1980, 15(4), 175-181.

13. Kallury, R. K. M. R.; Loudon, A. G.; Maccoll, A. Electron Impact Studies on $\alpha, \beta$-Unsaturated Carbonyl Oximes. Org. Mass Spectrom. 1978, 13(4), $218-223$.

14. Ardanaz, C. E.; Kavka, J.; Curcuruto, O.; Traldi, P.; Guidugli, F. On the Structure of $\left[\mathrm{C}_{9} \mathrm{H}_{6} \mathrm{O}\right]^{+}$Ions Originating by Electron Impact Induced Decomposition of Chalcone. Rapid Commun. Mass Spectrom. 1991, 5(11), 569-573.

15. Ardanaz, C. E.; Traldi, P.; Vettori, U.; Kavka, J.; Guidugli, F. The Ion-Trap Mass Spectrometer in Ion Structure Studies. The Case of [M $\mathrm{H}^{+}$ions from chalcone. Rapid Commun. Mass Spectrom. 1991, 5, 5-10.

16. Tai, Y.; Pei, S.; Wan, J.; Cao, X.; Pan, Y. Fragmentation Study of Protonated Chalcones by Atmospheric Pressure Chemical Ionization and Tandem Mass Spectrometry. Rapid Commun. Mass Spectrom. 2006, 20, 994-1000

17. Bohme D. K.; Schwarz, H. Gas-Phase Catalysis by Atomic and Cluste Metal Ions: The Ultimate Single-Site Catalysts. Angew. Chem. Int. Ed. 2005, 44, 2336-2354.

18. O'Hair, R. A. J. The 3D Quadrupole Ion Trap Mass Spectrometer as a Complete Chemical Laboratory for Fundamental Gas-Phase Studies of Metal Mediated Chemistry. Chem. Commun. 2006, 14, 1469-1481.

19. Kingston, E. E.; Beynon, J. H.; Liehr, J. G.; Meyrant, P.; Flammang, R.; Maquestiau, A. The Claisen Rearrangement of Protonated Allyl Phenyl Ether. Org. Mass Spectrom. 1985, 20, 351-359. 
20. Moolayil, J. T.; George, M.; Srinivas, R.; Swamy, N. S.; Russell, A.; Giblin, D.; Gross, M. L. The Mass Spectrometry-Induced Cyclization of Protonated N-[2-(Benzoyloxy)Phenyl]-Benzamide: A Gas-Phase Analog of a Solution Reaction. Int. J. Mass Spectrom. 2006, 249/250, 21-30.

21. Bohme, D. K. Proton Transport in the Catalyzed Gas-Phase Isomerization of Protonated Molecules. Int. J. Mass Spectrom. Ion Processes 1992 115, 95-110.

22. Chalk, A. J.; Radom, L. Proton-Transport Catalysis: A Systematic Study of the Rearrangement of the Isoformyl Cation to the Formyl Cation. J. Am. Chem. Soc. 1997, 119, 7573-7578.

23. Chalk, A. J.; Radom, L. Ion-Transport Catalysis: Catalyzed Isomerizations of $\mathrm{NNH}^{+}$and $\mathrm{NNCH}_{3}^{+}$. J. Am. Chem. Soc. 1999, 121, 1574-1581.

24. Ruttink, P. J. A.; Burgers, P. C.; Fell, L. M.; Terlouw, J. K. Dissociation of Ionized 1,2-Ethanediol and 1,2-Propanediol: Proton-Transport Catalysis with Electron Transfer. J. Phys. Chem. 1998, 102, 2976-2980.

25. Trikoupis, M. A.; Terlouw, J. K.; Burgers, P. C. Enolization of Gaseous Acetone Radical Cations: Catalysis by a Single Base Molecule. J. Am. Chem. Soc. 1998, 120(46), 12131-12132.

26. Trikoupis, M. A.; Burgers, P. C.; Ruttink, P. J. A.; Terlouw, J. K. Benzonitrile Assisted Enolization of the Acetone and Acetamide Radical Cations: Proton-Transport Catalysis Versus an Intermolecular H+/D+ Transfer Mechanism. Int. J. Mass Spectrom. 2001, 210/211, 489-502.

27. Wang, X.; Holmes, J. L. A Study of the Isomerization and Dissociation of Formal [Acetone-Methanol] ${ }^{+\cdot}$ Ion-Molecule Complexes. Can. J. Chem. 2005, 83, 1903-1912 and references therein.

28. Wang, X.; Holmes, J. L. Exploring the Potential Energy Surface of Ion-Molecule Pairs by Experiment and by Theory: Acetaldehyde and Methanol. Int. J. Mass Spectrom. 2005, 242, 75-85.

29. Sutton, R. Esters and Flavenes from 2-Hydroxychalcones and Flavylium Salts. J. Org. Chem. 1972, 37(7), 1069-1070

30. Hendley, E. C.; Neville, O. K. Carbon14 Tracer Studies in the Rearrangements of Unsymmetrical $\alpha$-Diketones. III. p-Methoxybenzylideneacetophenone Oxide. J. Am. Chem. Soc. 1953, 75, 1995-1996.

31. Becker, H. D.; Bremholt, T. Oxidative Rearrangement of $o$-Hydroxydiarylcarbinols. Tetrahedron Lett. 1973, 6), 197-200.

32. Gross, M. L. Tandem Mass Spectrometry: Multisector Magnetic Instruments. In Methods in Enzymology, Vol. CXCIII, Mass Spectrometry. McCloskey, J. A., Ed. Academic Press: San Diego, 1990; p. 131-153.

33. Stewart, J. J. P.; Frank, J. S. Optimization of Parameters for SemiEmpirical Methods. I. Method. J. Comp. Chem. 1989, 10, 209-220.

34. Stewart, J. J. P.; Frank, J. S. Optimization of Parameters for SemiEmpirical Methods. II. Applications. I. Comp. Chem. 1989, 10, 221-264.

35. Wittbrodt, J. M.; Schlegel, H. B. Some Reasons Not to Use Spin Projected Density Functional Theory. J. Chem. Phys. 1996, 105, 6574-6577.

36. Baker, J.; Scheiner, A.; Andzelm, J. Spin Contamination in Density Functional Theory. J. Chem. Phys. Lett. 1993, 216, 380-388.

37. Laming, G. J.; Hardy, N. C.; Amos, R. D. Kohn-Sham Calculation on Open-Shell Diatomic Molecules. Mol. Phys. 1993, 80, 1121-1134.
38. Nicolaides, A.; Smith, D. M.; Jensen, F.; Radom, L. J. Phenyl Radical, Cation, and Anion. The Triplet-Singlet Gap and Higher Excited States of the Phenyl Cation. J. Am. Chem. Soc. 1997, 119, 8083-8088.

39. Frisch, M. J.; Trucks, G. W.; Schlegel, H. B.; Scuseria, G. E.; Robb, M. A.; Cheeseman, J. R.; Zakrzewski, V. G.; Montgomery, J. A. Jr.; Stratmann, R. E.; Burant, J. C.; Dapprich, S.; Millam, J. M.; Daniels, A. D.; Kudin, K. N.; Strain, M. C.; Farkas, O.; Tomasi, J.; Barone, V.; Cossi, M.; Cammi, R.; Mennucci, B.; Pomelli, C.; Adamo, C.; Clifford, S.; Ochterski, J.; Petersson, G. A.; Ayala, P. Y; Cui, Q.; Morokuma, K.; Malick, D. K.; Rabuck, A. D.; Raghavachari, K.; Foresman, J. B.; Cioslowski, J.; Ortiz, J. V.; Stefanov, B. B.; Liu, G.; Liashenko, A.; Piskorz, P.; Komaromi, I.; Gomperts, R.; Martin, R.L.; Fox, D. J.; Keith, T.; Al- Laham, M. A.; Peng, C. Y.; Nanayakkara, A.; Gonzalez, C.; Challacombe, M.; Gill, P. M. W.; Johnson, B.; Chen, W.; Wong, M. W.; Andres, J. L.; Gonzalez, C.; Head-Gordon, M.; Replogle, E. S.; Pople, J. A. Gaussian 98, Revision A6. Gaussian, Inc.: Pittsburgh PA, 1998.

40. Frisch, M. J.; Trucks, G. W.; Schlegel, H. B.; Scuseria, G. E.; Robb, M. A.; Cheeseman, J. R.; Montgomery, Jr., J. A.; Vreven, T.; Kudin, K. N.; Burant, J. C.; Millam, J. M.; Iyengar, S. S.; Tomasi, J.; Barone, V.; Mennucci, B.; Cossi, M.; Scalmani, G.; Rega, N.; Petersson, G. A.; Nakatsuji, H.; Hada, M. Ehara, M.; Toyota, K.; Fukuda, R.; Hasegawa, J.; Ishida, M.; Nakajima, T.; Honda, Y.; Kitao, O.; Nakai, H.; Klene, M.; Li, X.; Knox, J. E.; Hratchian, H. P.; Cross, J. B.; Adamo, C.; Jaramillo, J.; Gomperts, R.; Stratmann, R. E.; Yazyev, O.; Austin, A. J.; Cammi, R.; Pomelli, C. Ochterski, J. W.; Ayala, P. Y.; Morokuma, K.; Voth, G. A.; Salvador, P.; Dannenberg, J. J.; Zakrzewski, V. G.; Dapprich, S.; Daniels, A. D.; Strain, M. C.; Farkas, O.; Malick, D. K.; Rabuck, A. D.; Raghavachari, K.; Foresman, J. B.; Ortiz, J. V.; Cui, Q.; Baboul, A. G.; Clifford, S.; Cioslowski, J. Stefanov, B. B.; Liu, G.; Liashenko, A.; Piskorz, P.; Komaromi, I.; Martin, R. L.; Fox, D. J.; Keith, T.; Al-Laham, M. A.; Peng, C. Y.; Nanayakkara, A.; Challacombe, M.; Gill, P. M. W.; Johnson, B.; Chen, W.; Wong, M. W.; Gonzalez, C.; Pople, J. A. Gaussian 03, Revision C.02. Gaussian, Inc.: Wallingford CT, 2004

41. Scott, A. P.; Radom, L. Harmonic Vibrational Frequencies: An Evaluation of Hartree-Fock, Moller-Plesset, Quadratic Configuration Interaction, Density Functional Theory, and Semiempirical Scale Factors. J. Phys. Chem. 1996, 100, 16502-16513.

42. Bongiorno1, D.; Ceraulo1, L.; Lamartina1, L.; Natoli, M. C. Studies in Organic Mass Spectrometry. Part 25. Benzyl Ion Formation in Chemical Ionization (Methane or Isobutane) of Some ortho AlkylheteroSubstituted Diphenylcarbinols. Rapid Commun. Mass Spectrom. 2000, 14, 203-206.

43. Agozzino, P.; Ceraulo, L.; Ferrugia, M.; Lamartina, L. A New General Fragmentation Reaction in Mass Spectrometry. The HydrogenCarbon, Carbon-Carbon Double Rearrangement of 2-Heteroalkyl Substituted Diphenylmethyl Cations. Eur. Mass Spectrom. 1995, 1, 73-79. 